\title{
Role of Plasma Phospholipid Transfer Protein in Lipid and Lipoprotein Metabolism
}

\author{
John J. Albers ${ }^{*}$, Simona Vuletic, and Marian C. Cheung \\ Northwest Lipid Metabolism and Diabetes Research Laboratories, Division of Metabolism, \\ Endocrinology and Nutrition, Department of Medicine, School of Medicine, University of \\ Washington, 401 Queen Anne Ave N, Seattle, WA 98109, USA
}

\section{Abstract}

The understanding of the physiological and pathophysiological role of PLTP has greatly increased since the discovery of PLTP more than a quarter of century ago. A comprehensive review of PLTP is presented on the following topics: PLTP gene organization and structure; PLTP transfer properties; different forms of PLTP; characteristics of plasma PLTP complexes; relationship of plasma PLTP activity, mass and specific activity with lipoprotein and metabolic factors; role of PLTP in lipoprotein metabolism; PLTP and reverse cholesterol transport; insights from studies of PLTP variants; insights of PLTP from animal studies; PLTP and atherosclerosis; PLTP and signal transduction; PLTP in the brain; and PLTP in human disease.

PLTP's central role in lipoprotein metabolism and lipid transport in the vascular compartment has been firmly established. However, more studies are needed to further delineate PLTP's functions in specific tissues, such as the lung, brain and adipose tissue. Furthermore, the specific role that PLTP plays in human diseases, such as atherosclerosis, cancer, or neurodegenerative disease, remains to be clarified. Exciting directions for future research include evaluation of PLTP's physiological relevance in intracellular lipid metabolism and signal transduction, which undoubtedly will advance our knowledge of PLTP functions in health and disease.

\section{Keywords}

phospholipid transfer protein; PLTP gene organization and structure; PLTP transfer properties; forms of PLTP; plasma PLTP complexes; lipoprotein metabolism; reverse cholesterol transport; cholesterol efflux; PLTP variants; PLTP animal studies; PLTP and atherosclerosis; PLTP in signal transduction; PLTP in the brain; PLTP in human diseases

\section{Introduction}

Over the years, Dr. John "Jack" F. Oram collaborated with our laboratory on many different projects. His enthusiasm, scientific integrity, tenacious belief that regulation of cholesterol transfer from the periphery is an active and regulated process, and his tireless work to prove it have greatly contributed to our understanding of reverse cholesterol transport. Thus, he

\footnotetext{
(C) 2011 Elsevier B.V. All rights reserved.

"Corresponding author: John J. Albers, Ph.D. NWRL 401 Queen Anne Ave N Seattle, WA 98109 Phone: +1-206-685-3330 Fax: +1-206-685-3279 jja@uw.edu. Simona Vuletic: simona@uw.edu Marian C. Cheung: mccheung@uw.edu.

Publisher's Disclaimer: This is a PDF file of an unedited manuscript that has been accepted for publication. As a service to our customers we are providing this early version of the manuscript. The manuscript will undergo copyediting, typesetting, and review of the resulting proof before it is published in its final citable form. Please note that during the production process errors may be discovered which could affect the content, and all legal disclaimers that apply to the journal pertain.
} 
has indelibly changed the world of scientific thought and left a legacy upon which others will build for many years to come.

Among other projects that Jack was involved with, he collaborated with our laboratory on a long-term project to understand how phospholipid transfer protein (PLTP) and ATP binding cassette A1 (ABCA1) interact to regulate cellular reverse cholesterol transfer. His contributions opened new areas of PLTP research and enriched our understanding of this perplexing protein.

\section{PLTP Gene Organization and Structure}

PLTP belongs to the lipopolysaccharide (LPS) binding/lipid transfer gene family that includes the LPS binding protein (LBP), the neutrophil bactericidal permeability increasing protein (BPI) and the cholesteryl ester transfer protein (CETP) [1]. About 23-27\% of the amino acids of these proteins are identical to those of PLTP, and another $21 \%$ of the amino acids represent conserved substitutions. The PLTP gene spans about 13 kilobases and is comprised of 16 exons and 15 introns [2]. The PLTP gene organization closely resembles the gene organization of the other members of the LPS binding/lipid transfer gene family, and the exon-intron junctions among family members are highly conserved $[2,3]$. The similarity in gene structure and homology in coding sequences suggest that the members of this gene family are functionally related, and that they evolved from a common ancestral gene. Indeed, all these proteins have the ability to bind and transfer LPS and phospholipids $[4,5]$. The PLTP gene is localized on chromosome 20q12-13.1 [6], near the site for LBP and BPI (20q11.23). So far, studies have confirmed that PLTP gene expression is regulated by sterols, glucose and fenofibrates and the PLTP promoter is responsive to regulation through LXR/FXR and PPAR-dependent mechanisms [7-9].

PLTP is a 476 residue glycoprotein with an apparent molecular weight (MW) of about 80 $\mathrm{kDa}$, while the predicted protein MW is $53 \mathrm{kDa}$ (the mature protein without a leader peptide) [1]. The difference in MW between the protein moiety and the glycoprotein is almost entirely attributed to N-glycosylation at residues 47, 77, 100, 126, 228 and 381 [10]. The carbohydrates at the $\mathrm{N}$-glycosylation sites range in size from 3.1 to $4.2 \mathrm{kDa}$. The threedimensional structural model of PLTP, based on the crystal structure of BPI [11], predicts a boomerang-shaped molecule composed of two domains with similar folding and a hydrophobic pocket in each domain for binding the acyl chains of a phospholipid molecule.

\section{PLTP Transfer Properties}

Initial studies indicated that PLTP transfers phosphatidylcholine [12-14]. Subsequent studies revealed that PLTP facilitates the transfer of a spectrum of different lipid molecules, including diacylglycerol, phosphatidic acid, sphingomyelin, phosphatidylcholine (PC), phosphatidylglycerol, cerebroside and phosphatidyl ethanolamine [15, 16]. PLTP transfers the antioxidant $\alpha$-tocopherol, which raises the possibility that it plays a role in modulating oxidation of lipoproteins and tissues [17, 18]. PLTP can also modulate phosphatidylserine externalization in erythrocytes, which can have an impact on clotting time and the risk of thrombus formation [19]. Interestingly, recent studies suggest that PLTP may play a protective role in thrombosis [20,21]. Considering the large number of different amphipathic molecules that PLTP has been shown to transport, it is likely that PLTP transports other related bioactive amphipathic molecules. These transport functions undoubtedly play an important role in lipid and lipoprotein metabolism, not only in the vascular compartment, but also in a variety of tissues, as PLTP is nearly ubiquitously expressed $([1,22,23]$ and unpublished data). 


\section{Different Forms of PLTP}

Two forms of functionally defined PLTP exist in human plasma: an "active" form that can transfer PC from phospholipid vesicles to high-density lipoproteins (HDL), and an "inactive" form that lacks this capability [24-26]. Between 50\% and 90\% of PLTP mass in normal plasma has been reported to be in the inactive form [24, 25, 27, 28]. Active PLTP was located in plasma macromolecules with apparent mean MW of 160-210 kDa and Stokes diameter of 7.6-12.0 nm, the size of bulk HDL particles, while inactive PLTP was found predominantly in larger macromolecules, spanning the molecular size range from $340 \mathrm{kDa}$ to $>600 \mathrm{kDa}$ and Stokes diameters of 12 to $>17 \mathrm{~nm}$ [24-26, 28]. Small inactive PLTP complexes with mean apparent MW of $146 \mathrm{kDa}$ have also been detected. Their quantities varied widely among individuals, ranging from $1-28 \%$ of total plasma PLTP or 2-42\% of plasma inactive PLTP [28]. Large inactive PLTP complexes were nearly absent in the plasma of subjects with hypoalphalipoproteinemia such as Tangier disease, lecithin:cholesterol acyltransferase (LCAT) deficiency, apolipoprotein (apo) A-I deficiency, and familial HDL deficiency [29]. There was no evidence of inactive PLTP in human tear fluid, although the amount of PLTP in tear fluid was double that in plasma [30]. The conditioned media of human HepG2 hepatoma cells [31] and other cells [unpublished data] also do not contain the inactive form of PLTP. A high correlation between PLTP activity and protein (as measured by Western blot analysis) in cerebrospinal fluid (CSF), suggests that CSF also does not contain inactive PLTP ([23, 32] and unpublished data). Furthermore, the inactive form of PLTP has not been reported in other mammalian species. The plasma level of inactive PLTP decreased with systemic and acute phase response [33, 34] and with intravenous infusion of apoA-I/PC discs [35], but increased with antibiotic treatment of periodontitis [36]. Thus, inactive PLTP, which is present mainly in the vascular compartment in humans, is a dynamic pool of protein responsive to physiological and pathophysiological changes.

The molecular differences between active and inactive PLTP are not known. Both forms of PLTP migrate at a comparable position corresponding to $80 \mathrm{kDa}$ when analyzed by SDS gel electrophoresis, and both also bind heparin [24, 25]. We found that both active and inactive PLTP forms are predominantly associated with apoA-I, but not with apoE, as anti-apoA-I immunoadsorbent removed essentially all PLTP activity and mass, while anti-apoE immunoadsorbent removed little PLTP activity and mass from plasma [37]. In contrast, Kärkkäinen et al. reported that apoE was enriched in isolated active PLTP complexes, while isolated inactive PLTP complexes contained apoA-I [25]. The reason for this divergent observation is not clear, but could be due to the use of heparin-Sepharose in the isolation procedure [25]. Heparin binds both PLTP and apoE, but not apoA-I. Its use could have selectively desorbed PLTP and apoE from PLTP-containing complexes and lipoproteins, resulting in remodeling of native active and inactive plasma PLTP complexes, and the coisolation of apoE with PLTP. Since apoE can bind PLTP, and proteoliposomes containing apoE can activate inactive PLTP [38], co-isolation and enhancement of apoE in PLTP complexes would be expected to enhance PLTP activity, and is consistent with the suggestion that apoE may play a role in regulating the PLTP activity level in plasma [38].

The physiological function of inactive PLTP is at present unknown. Although inactive PLTP purified from human plasma cannot deliver lipid from PC-containing vesicles to acceptor HDL, nor can it mediate HDL conversion, generate preß-HDL, or promote cholesterol efflux from macrophages [39], its lipid binding capacity is equal to that of active PLTP, and, like active PLTP, it can enhance the desorption of PC from vesicles [40]. Active and inactive PLTP are surface-active proteins, and inactive PLTP docked more strongly onto a phospholipid monolayer surface than active PLTP [40]. Thus, inactive PLTP may play other 
important lipid transfer-independent functions on cell surfaces, such as activation of signal transduction. (See section on the Role of PLTP in Signal Transduction.)

\section{Characteristics of Plasma PLTP Complexes}

Plasma PLTP complexes containing the active and inactive forms of PLTP, isolated using anti-PLTP antibodies, have recently been studied [41]. The apparent MW of these immunoaffinity-isolated PLTP complexes (as assessed by both mass and activity) ranged from $\sim 160$ to $>670 \mathrm{kDa}$, which is consistent with the size distribution of PLTP in whole plasma [24]. Shotgun proteomics revealed the presence of 24 proteins, with clusterin (apoJ) being the major identified protein, followed by fibrinogen, transthyretin, PLTP, plasminogen and apoA-I. Based on the molar ratio of PLTP with other major proteins found in the complexes and our estimate of the molecular size of these complexes, it is likely that there is only one PLTP per complex. While PLTP co-elutes with HDL on size exclusion chromatography, and PLTP is associated with apoA-I, the protein repertoire and lipid content of PLTP complexes are distinct from HDL isolated by ultracentrifugation or immunoaffinity chromatography. Because lipids account for only $3 \%$ of the PLTP complexes, it is likely that protein-protein interactions, rather than protein-lipid interactions, drive the assembly of PLTP complexes. Furthermore, while differences in HDL size are primarily determined by the lipid to protein ratio in the particles, differences in the size of the PLTP complexes are likely primarily due to the nature and the number of proteins in the PLTP complexes. Indeed, 20 of the 24 proteins have experimentally documented interaction according to the protein-protein interaction database, and direct PLTP interactions were documented for apoA-I, apoE, clusterin, complement $\mathrm{C} 1 \mathrm{r}$, transthyretin, fibrinogen, and plasminogen. ApoA-I, apoE, clusterin, and to a lesser extent complement C1r were able to significantly stabilize recombinant PLTP's lipid transfer activity, while PLTP activity was significantly lower in the presence of plasminogen [41]. The observations that proteins associated with PLTP complexes can stabilize, enhance, or inhibit the lipid transfer activity of PLTP, and that purified inactive PLTP complexes could be activated by incubation with proteoliposomes containing apoE or apoA-IV [38], suggest that compositional differences between active and inactive complexes may be the biochemical basis for the lack of phospholipid transfer activity in inactive complexes.

Only six of the 24 proteins in PLTP complexes are apolipoproteins (A-I, A-II, D, E, J, and L1). Surprisingly, 14 of the 24 proteins are acute phase response proteins whose plasma concentrations are changed markedly by inflammation, and eight proteins are involved with complement regulation. The association of proteins with established functions in inflammation and immunity with PLTP and the increase of PLTP activity in sepsis and acute phase response [33, 34, 42] suggest that besides participating in lipid transport, PLTP plays previously unsuspected roles in immunity and inflammatory pathways. PLTP is expressed in many types of cells and tissues with different functions [22, 43] including macrophages [44, 45], key cells of the innate immune system. The wide array of functionally distinct proteins detected in affinity-isolated plasma PLTP complexes and the size heterogeneity of those complexes may reflect multiple origins and functions of plasma PLTP. Additional research is needed to separate the various subpopulations of the heterogeneous plasma PLTP complexes and identify their functions.

\section{Relationship of Plasma PLTP Activity, Mass, and Specific Activity with Lipoproteins and Metabolic Factors}

Plasma PLTP activity can be monitored by its ability to mediate the transfer of phospholipids from plasma very low density lipoproteins (VLDL) and low density lipoproteins (LDL) [46] or from synthetic liposomes [27] to plasma HDL. Plasma PLTP 
activity measured with the endogenous assay is lipoprotein-dependent, and the ratio of phospholipids in the donor and acceptor particles varies with the nature and relative amounts of VLDL, LDL and HDL in the samples analyzed. Endogenous PLTP activity is most strongly and positively correlated with plasma triglyceride $[27,46]$ and with the triglyceride in HDL [46]. This correlation is likely due to the enhanced ability of triglyceride-rich HDL to accommodate additional phospholipids [47].

PLTP activity can also be measured by its ability to transfer phospholipids from ${ }^{14} \mathrm{C}$-labeled phospholipid liposomes to purified HDL (exogenous activity). The transfer of phospholipids from liposomes to HDL is specific for PLTP, as anti-PLTP antibodies can inhibit essentially all such transfer [46]. Exogenous PLTP activity is not influenced by the nature and quantities of lipoproteins in the test samples [46]. Thus, it is the conventional method for measuring PLTP activity in plasma and other body fluids, as well as in cell culture studies. It should be noted however, that while this assay is specific for PLTP, observed PLTP activity is assay-dependent, because the characteristics of the donor and acceptor particles and incubation conditions can influence the rate of phospholipid transfer from liposomes to HDL. Reported mean serum or plasma PLTP activity in healthy adults among different laboratories ranged from 0.58 to $13.5 \mu \mathrm{mol} / \mathrm{ml} / \mathrm{h}$ [46, 48-51]. No gender differences in plasma PLTP activity were observed in these and other [27, 52] studies, although PLTP activity appears to increase with age $[34,49,53]$ and with body mass index (BMI), obesity, and insulin level [49, 51-57]. PLTP activity was also higher in patients with type 1 and type 2 diabetes compared to non-diabetic controls [48, 53, 58-60], and was increased in systemic and acute inflammatory responses [33, 34, 42]. PLTP activity was correlated with the inflammatory marker C-reactive protein (CRP) in the acute phase response [34, 42] and in patients with cardiovascular disease [55] or with type 2 diabetes [60], two disorders linked to systemic inflammation, but not in a random healthy population [27]. Interestingly, CRP was a significant independent determinant of plasma PLTP activity in these two patient groups. It has been suggested that increased PLTP may enable more transfer of phospholipids to cells to maintain membrane integrity under conditions of inflammatory stress $[33,42]$.

The association of plasma PLTP activity with lipoproteins has been extensively studied. Although findings are not always consistent among study populations with different lipid and metabolic characteristics, many studies have shown that plasma PLTP activity is positively associated with plasma cholesterol, triglyceride, apoB, VLDL and intermediate density lipoproteins (IDL) [27, 49-52, 56, 58, 61], and there is evidence that gender- and obesity-related factors, such as hormones and hepatic triglyceride lipase, can modulate these associations [52, 56, 62]. Of the many metabolic and lipoprotein parameters often found to be significantly associated with PLTP activity, triglyceride was the only parameter that contributed significantly to the variation of plasma PLTP activity in a cohort of healthy men and women, explaining 35\% of its variance [51]. In these subjects, the positive association of BMI, cholesterol, apoB, and VLDL particles with PLTP activity disappeared after controlling for triglyceride, suggesting that their association with PLTP activity was primarily due to their mutual association with triglyceride. In type 2 diabetic patients with increased plasma apoE levels, apoE accounted for $23 \%$ of their plasma PLTP activity, compared to $8 \%$ in controls [53].

Plasma PLTP mass is measured with either sandwich or competitive enzyme-linked immunosorbent assays (ELISA) using polyclonal and monoclonal anti-PLTP antibodies [48, $50,51,61]$. These ELISAs use different antibodies and calibration materials. Mean total serum or plasma PLTP concentration in healthy, normolipidemic subjects measured with these assays ranged from 1.6 to $15.6 \mathrm{mg} / \mathrm{L}$. As with PLTP activity, no gender difference in plasma PLTP mass was seen in these studies. Moreover, most studies found that plasma 
PLTP mass was strongly and positively associated with HDL cholesterol, specifically with $\mathrm{HDL}_{2}$ cholesterol, large HDL particles, and mean HDL particle size, but was inversely associated with triglyceride and BMI [27, 50, 51, 61, 63, 64]. The strong correlation between PLTP mass and the various HDL parameters was independent of triglyceride [51], and in linear models HDL cholesterol was the best predictor of PLTP mass, explaining about $25 \%$ of its variation in plasma [51,63]. Consistent with these observations, plasma PLTP concentration was significantly lower in subjects with hypoalphalipoproteinemia (Tangier disease, LCAT deficiency, apoA-I deficiency, and familial HDL deficiency), and significantly higher in those with hyperalphalipoproteinemia associated with cholesteryl ester transfer protein deficiency, when compared to subjects with normal HDL levels [29]. The differential association of plasma PLTP mass and activity with HDL and triglyceride is also consistent with the lack of bivariate correlation between these two PLTP parameters observed in many studies [29, 50, 51, 61, 64], unless controlled for triglyceride [51, 61, 64].

An ELISA has also been developed to quantitate the two forms of PLTP in serum [65]. Mean level of active and inactive PLTP in 250 normolipidemic blood samples obtained from a random Finnish population was $3 \mathrm{mg} / \mathrm{L}$ and $3.56 \mathrm{mg} / \mathrm{L}$, respectively [27]. Thus, inactive PLTP averaged about $55 \%$ of total serum PLTP, comparable to the $60 \%$ calculated from the distribution of PLTP mass and activity upon separation of plasma samples on size exclusion chromatography [28]. Individual variation existed between the relative amounts of the active and inactive PLTP in blood samples [27, 28]. The concentration of active PLTP was significantly associated with HDL cholesterol, apoA-I, and PLTP activity. No correlation was observed between the level of inactive PLTP in sera and lipoproteins [27].

Besides variation in PLTP mass and activity, PLTP specific activity (SA), calculated from the measured PLTP activity and mass, also varied among blood samples [50, 51, 61]. This variation was not only due to the differences in the relative amounts of active and inactive PLTP in the samples [27, 28], but also due to variation in the SA of active PLTP [28]. Serum or plasma PLTP SA has been found to be positively correlated with BMI, cholesterol, triglyceride, LDL cholesterol, and apoB, but inversely associated with HDL cholesterol [51, 61]. It was also positively associated with VLDL and IDL particles, and inversely associated with large LDL particles, large HDL particles, and mean LDL and HDL particle size in healthy men and women [51]. Multiple linear regression analysis indicated that mean HDL size alone could explain $45 \%$ of the variance of plasma PLTP in these subjects. If lipoprotein particles were excluded from the regression analysis, both triglyceride and HDL cholesterol were significantly associated with plasma PLTP SA, with triglyceride enhancing and HDL cholesterol reducing plasma PLTP SA.

The cumulative findings on the association of plasma PLTP activity, mass, and SA with lipoproteins provide strong evidence for a metabolic relationship between select lipoproteins and plasma PLTP level and activity. Specifically, in healthy subjects, triglyceride, HDL cholesterol, and HDL particle size are significant independent modulators of plasma PLTP activity, mass, and SA, respectively [51]. Importantly, the observation that the inverse association between plasma PLTP SA and HDL particles was confined to large HDL particles suggests the possibility that PLTP associated with large particles has lower SA than PLTP associated with small particles, providing an explanation for the findings that most inactive PLTP complexes in plasma are larger than active PLTP complexes. These findings allow us to formulate the following working hypotheses on the origin of inactive PLTP complexes, and the regulation of the pool size of active and inactive PLTP: as active PLTP is associated with small HDL particles, and the inactive form is located predominantly on large HDL particles, we hypothesize that inactive PLTP is generated in the vascular compartment during the conversion of nascent HDL to mature large HDL particles. In vitro studies suggest that cells secrete only active PLTP [31]. Thus inactive PLTP is formed as 
lipid is transferred from apoB-containing lipoproteins or cells to HDL particles. The lack of correlation between PLTP activity and mass in many studies [29, 50, 51, 61, 64] suggests that plasma PLTP activity can increase or decrease without a parallel change in PLTP protein. To explain this phenomenon, we further propose that inactive PLTP can regain its phospholipid transfer activity when large HDL or large PLTP complexes are catabolically converted into smaller HDL or PLTP complexes. This HDL-dependent interconversion of PLTP of low and high SA could be a mechanism through which PLTP activity, and consequently the pool size of active and inactive PLTP, is regulated in vivo, providing an explanation of a significant association of PLTP SA with HDL particle size. The concept of interconversion between active and inactive PLTP complexes is consistent with the significant inverse correlation between the levels of these two forms of PLTP in human serum [27], and with the observation that apoE and apoA-IV proteoliposomes can activate inactive PLTP [38]. Based on these hypotheses, inactive PLTP serves as a reservoir of PLTP whose pool size is regulated by cellular and vascular proteins and lipoproteins, and it can be rapidly converted to active PLTP as needed. However, as discussed in subsequent sections, there is evidence that PLTP that is inactive in lipid transfer may play other important physiological functions. Further research is needed to better document the interconversion of plasma active and inactive PLTP complexes, and determine factors that regulate these conversions.

\section{Role of PLTP in Lipoprotein Metabolism}

The key role of PLTP in lipoprotein metabolism undoubtedly centers on its lipid transport function of transferring phospholipids between HDL particles and of lipids between apoBcontaining lipoproteins and HDL. In this latter capacity, during lipolysis of chylomicrons and very low density lipoproteins (VLDL) by lipoprotein lipase, PLTP is essential for the transfer of excess surface lipids from triglyceride-rich lipoproteins to HDL [66, 67] and thereby, facilitates the formation of smaller lipoprotein remnants, contributes to the formation of LDL, and assists in the maturation of HDL particles. Furthermore, PLTPmediated phospholipid transport among HDL particles is another mechanism whereby PLTP modulates HDL size and composition. This so-called HDL conversion into larger and smaller particles was first described by Rye and Barter [68] and subsequently shown to be mediated by PLTP $[69,70]$. This process involves the transfer of surface lipids, the formation of enlarged HDL through particle fusion, and the formation of small lipid-poor apoA-1/phospholipid complexes with pre $\beta$-mobility [71].

There are several possible models to describe the sequence of events involved in the HDL conversion process. One model suggests that after initial PLTP binding to phospholipids on the surface of HDL particles, small lipid-poor apoA-I/phospholipid complexes dissociate from the particles, which causes the formation of unstable surface-depleted HDL particles that subsequently fuse to form new, enlarged, stable particles [22, 71]. Alternatively, PLTP binding and/or PLTP-mediated phospholipid transfer would promote the fusion of two HDL particles to form an unstable, enlarged fusion intermediate, which would dissociate its excess surface lipid with apoA-I to form lipid-poor pre $\beta$-HDL and the remaining enlarged HDL particle would stabilize $[47,72]$. Both of these mechanisms are perfectly plausible. Perhaps the nature of the HDL particle would dictate which comes first, particle fusion or dissociation of lipid-poor apoA-I/phospholipid complexes. Thus, PLTP-mediated conversion of $\mathrm{HDL}_{2}$ particles [73] may follow a different sequence than the conversion of nascent discoidal HDL particles into vesicular structures $[67,74]$, and in part be dependent on the amount of PLTP binding to the HDL particle [75] and the concomitant modulation of the HDL particle by other proteins, such as hepatic lipase, CETP, and LCAT. The HDL protein composition can also influence the PLTP-mediated HDL conversion process [76]. We have reported that PLTP promotes the conversion of both LpA-I and LpA-I/A-II HDL particles 
into larger and smaller particles, but the size distribution before and after incubation with PLTP differs significantly between these two HDL subpopulations. Triglyceride-enriched HDL particles display an enhancement of PLTP-mediated HDL conversion, presumably, because triglyceride-rich particles are more unstable $[47,76]$.

\section{PLTP and Reverse Cholesterol Transport}

Studies of reverse cholesterol transport by Jack Oram were pivotal for our understanding of PLTP's function in that process. PLTP plays a key role in the uptake of cholesterol from peripheral cells and tissues that is subsequently transported to the liver for degradation and excretion [77]. PLTP facilitates the efflux of cholesterol from peripheral cells through multiple mechanisms. First, PLTP promotes cell-surface binding and remodeling of HDL, which improves the ability of HDL to remove cholesterol and phospholipid from cells [77]. During the PLTP-mediated conversion process, small apoA-I particles and large fused HDL particles are generated [70,78]. The small particles have been shown to correspond to pre $\beta_{2}$ HDL [79], and this HDL subclass serves as the preferred initial acceptor for cellderived cholesterol [80]. The large fused HDL particles generated by PLTP are, reportedly, efficient cholesterol acceptors [39]. We postulate that PLTP also plays a role in the generation of apoA-I/phospholipid complexes, perhaps analogous to nascent apoA-I particles secreted from the liver and intestine that are precursors of efficient cholesterol acceptors, but may require interaction with ABCA1-expressing cells before they can be converted to pre $\beta$ HDL cholesterol acceptors $[67,77]$. Pre $\beta$ HDL precursors could be generated by PLTP as it transfers apoA-I/phospholipid complexes from chylomicrons during lipolysis. Thus, the continued PLTP-mediated generation of efficient acceptors of cellular cholesterol and their precursors is one of the important ways PLTP facilitates reverse cholesterol transport.

A robust reverse cholesterol transport system is essential to prevent excessive accumulation of cholesterol in arterial macrophages. We and others have shown that PLTP is expressed in macrophages, its expression is upregulated in cholesterol-laden macrophages, and it is present in atherosclerotic lesions [44, 45, 81]. Our studies in collaboration with Jack Oram have indicated that PLTP enhances cholesterol and phospholipid efflux from cholesterolloaded macrophages and fibroblasts [77, 82]. PLTP-mediated lipid efflux could occur in both an autocrine and paracrine manner.

When ABCA1 is induced by cholesterol loading of cells, ABCA1 constitutively generates cholesterol and phospholipid membrane domains [83]. Our work with Jack Oram is consistent with the model that PLTP binds directly to the protruding lipid domains, which are in close association with ABCA1 [82]. At the same time, we have shown that PLTP can bind directly to $\mathrm{ABCA} 1$ and stimulate JAK2 phosphorylation, which in turn increases binding of PLTP or apolipoproteins to ABCA1-induced lipid domains [84]. As a result, the surface lipids are solubilized and removed from the cells by PLTP and subsequently shuttled to lipoprotein acceptor particles. Alternatively, a PLTP-lipoprotein complex could interact directly with the cell surface lipid domains generated by ABCA1 and thereby, remove the lipids from the cell surface. The addition of exogenous PLTP to cholesterol-loaded J774 macrophages was able to stabilize ABCA1 [82]. Thus, the ABCA1-dependent pathway is an efficient pathway for removing excess cholesterol from cholesterol-loaded macrophages. The relevance of PLTP in ABCA1-dependent lipid efflux has been confirmed by in vivo studies showing that PLTP deficiency in mice impairs ABCA1-dependent efflux of cholesterol from macrophage foam cells [85]. While apoA-I can also solubilize lipids from the cell surface lipid domains [86] and interacts with ABCA1 to enhance lipid efflux, apoA-I tissue expression is limited to the liver and intestines, while PLTP is expressed by virtually all cells. Therefore, the role of PLTP in reverse cholesterol transfer may be critical under 
conditions with limited apoA-I availability. For example, PLTP expressed locally by macrophages in the vascular wall could play an important role in limiting foam cell formation, thus reducing development of atherosclerotic plaques. Furthermore, local presence of PLTP in peripheral tissues could be relevant in enhancing reverse cholesterol transport through its participation in the ABCA1-dependent lipid export pathway.

Further support for PLTP's role in macrophage cholesterol efflux is suggested by reports showing that the sterol-responsive liver X receptor induces PLTP along with other key proteins involved in cholesterol efflux, including ABCA1, ABCG1 and apoE [87-90]. We have shown that exogenous PLTP added to primary human astrocytes induces apoE secretion [32], and macrophage PLTP deficiency in mice causes a significant reduction in apoE secretion from macrophages [91]. These reports support the idea that PLTP modulates apoE expression in peripheral cells. ApoE has been shown to facilitate lipid efflux from macrophages [92, 93], and apoE deficiency in macrophages is sufficient to impair reverse cholesterol transport [94]. Thus, PLTP's ability to modulate cellular apoE production is another mechanism whereby PLTP could promote lipid efflux from peripheral cells.

\section{Insights from Studies of PLTP Variants}

Several early studies have suggested that common single nucleotide polymorphisms (SNPs) at the PLTP locus can affect plasma levels of HDL cholesterol [95-97]. An allele of SNP rs7679, near the PLTP locus, was reported to be associated with higher HDL cholesterol, lower plasma triglyceride, higher PLTP transcript levels [98], and higher plasma PLTP activity [99]. Jarvik and colleagues in collaboration with our laboratory reported that the minor allele of the intronic PLTP SNP rs6065904 was associated with elevated PLTP activity and predicted carotid artery disease in a case-control study [99]. On the other hand, the allele of SNP rs2294213 in intron 1 of PLTP, which was shown to be associated with increased HDL cholesterol [97] and elevated plasma PLTP activity, was not associated with carotid artery disease [99]. Four other PLTP SNPs, three intronic and one in the 5' region, were not associated with carotid artery disease, but were consistently associated with PLTP activity. Findings from a combination of five cardiovascular disease (CVD) case-control studies showed that genetic variation at the PLTP locus was associated with the incidence of cardiovascular disease [100]. Among six intronic PLTP tag SNPs examined, only rs378114 and rs6065904 were consistently associated with plasma PLTP activity levels. Therefore, the authors constructed a gene score on the basis of the effects on lowering PLTP activity by the $\mathrm{G}$ allele of 378114 and the $\mathrm{T}$ allele of rs6065904 and demonstrated that an increase in gene score was associated with a decrease in PLTP transcript levels in human liver, an increase in concentration of small HDL particles, and a smaller HDL size as measured by nuclear magnetic resonance spectroscopy or gradient gel electrophoresis. Additionally, an inverse association between PLTP gene score and risk of CVD was found in four of the five casecontrol studies. Meta-analysis of lipid genome-wide association studies (GWAS) found that the minor allele of PLTP SNPs rs6065906 and rs378114 were associated with decreased HDL cholesterol [101], while rs4810479 was associated with smaller HDL size [102].

These studies indicate that common variants at the PLTP locus identified through GWAS explain a small proportion of the variation in HDL cholesterol, HDL size, or HDL particle number. It is difficult to know which of the variants are responsible for the changes in HDL, due to linkage disequilibrium among variants. Furthermore, adjustment for non-genotype covariates can remove the relationship of the HDL parameters with those SNPs found to be associated with PLTP activity [99], and these association studies do not elucidate the pathway leading to the effect of the variant. Nevertheless, these studies support the concept that PLTP activity modulates HDL cholesterol or HDL size, with a lower PLTP activity associated with an increase in smaller HDL particles. Further studies, following the 
approach of Vergeer et al. [100], by using a gene score that denotes the presence of multiple PLTP allelic variants that exhibit changes in PLTP function, and subsequent evaluation of changes in phenotype, show promise in providing further insight into the biological impact of changes in PLTP activity or functionality. The identification of rare PLTP variants that have greater impact on PLTP functionality than the common variants would likely be more useful to improve our understanding of the biological or therapeutic relevance of alterations in PLTP activity or functionality.

The studies of Vergeer et al. [100] suggest that reduced PLTP activity results in an increase in HDL particles of smaller size and these changes in HDL may be involved in mediating the reduced CVD susceptibility associated with a combination of PLTP genotypes. There are several reasons why this proposition may not be valid. First, statistical adjustment for HDL particle parameters in the multivariate regression model did not reduce the statistical significance of the relationship between the PLTP gene score and CAD risk [100]. Second, multiple PLTP variants were found to be predictive of plasma PLTP activity, but were not associated with carotid artery disease [99]. Third, we have not observed a significant relationship between HDL particle number or HDL size and plasma PLTP activity, but we do observe a highly significant inverse relationship between PLTP specific activity (PLTP activity/PLTP mass) and HDL size [51]. Fourth, we have reported that the spectrum of HDL particle sizes tends to be shifted towards smaller particles in patients with CVD [103]. Furthermore, two large prospective studies have shown that the incidence of CVD is inversely related to the levels of large HDL $[104,105]$. Thus, it does not appear likely that the decreased CVD risk associated with PLTP SNPs leading to decreased PLTP expression or reduced plasma PLTP activity is a consequence of an increase in smaller size HDL. Although it is possible that smaller HDL, induced by having less PLTP, has improved lipid efflux properties or causes other improvements in HDL functionality, evidence for this possibility is lacking. Thus, the basis for a relationship between the PLTP gene variation and CVD remains to be clarified.

\section{Insights of PLTP from Animal Studies}

The vast majority of studies concerning the role of PLTP in lipoprotein metabolism in animals have been conducted in C57BL/6 mice. The initial landmark studies carried out on mice with a targeted mutation of the PLTP gene, resulting in no PLTP gene expression, indicated that PLTP deficiency in mice on a chow diet causes a marked decrease in HDL lipid and apolipoproteins, and the abolishment of the in vivo transfer of $\left[{ }^{3} \mathrm{H}\right]$ phosphatidylcholine from VLDL to HDL [106]. However, no significant differences in non-HDL lipid or apoB levels were evident between PLTP-deficient and wild-type littermates on the chow diet. Placement of mice on a high fat/high cholesterol diet for two weeks was associated with significantly higher VLDL/LDL lipids; however, no differences in apoB levels were reported in PLTP-deficient mice compared to the wild type mice. These seminal findings indicated that, in this mouse model, PLTP specifically mediates the transfer of phospholipids and free cholesterol from triglyceride-rich lipoproteins into HDL, and provided further support to the initial suggestions that PLTP plays a major role in the transfer of surface lipids from triglyceride-rich lipoproteins to HDL during lipolysis [66]. It is important to note that the heterozygote PLTP-deficient mouse that has about half of its phospholipid transfer protein activity depleted, did not display any significant changes in plasma lipoprotein levels. This observation suggests that even less than normal plasma PLTP activity is sufficient to transfer lipids to HDL and provide stability to HDL particles. Interestingly, when these PLTP-deficient mice are bred into either apoE-deficient or apoBtransgenic backgrounds, PLTP deficiency results in reduced production and levels of apoBcontaining lipoproteins [107]. On the basis of this observation, it has been concluded that PLTP regulates apoB secretion. The putative mechanism responsible for the observed 
reduction of apoB in PLTP-deficient mice appears to be due to a decrease in liver vitamin E content and substantial enhancement of reactive oxygen species-dependent destruction of newly synthesized apoB in this specific mouse model [108]. If PLTP does indeed regulate apoB secretion, one might expect that an increase in PLTP expression would enhance VLDL and LDL levels. However, a two-fold increase in PLTP levels in apoE-deficient mice did not result in any changes in non-HDL cholesterol or phospholipid, but did result in a decrease in $\alpha$-tocopherol/lipid ratio in all lipoprotein fractions, indicating that PLTP plays a role in the plasma $\alpha$-tocopherol distribution in this mouse model [109]. Overexpression of human PLTP in other mouse models also indicates little impact on LDL or VLDL [110, 111]. A recent study of transgenic rabbits expressing human PLTP showed that the transgenic animals on a chow diet exhibited an increase in the cholesterol content of the apoBcontaining lipoproteins, but no significant change in apoB [112]. However, both the cholesterol content and apoB levels were significantly increased in the transgenic rabbits as compared to the non-transgenic ones, when the rabbits were fed a cholesterol-rich diet.

Comparison of PLTP transgenic mice with a modest increase in PLTP expression to control littermates did not reveal any significant changes in plasma lipoprotein lipids or apolipoproteins [113]. However, when these mice were crossbred onto a human apoA-I transgenic background, the animals with the human PLTP, e.g. the double transgene, had significantly higher level of HDL lipids and apoA-I, and had a major increase in prebetaHDL. Furthermore, a more pronounced increase in PLTP expression resulted in accelerated HDL catabolism and marked decrease in HDL levels along with an increase in prebeta-HDL generation [114-117].

Increased expression of PLTP in various mouse models has lead to inconsistent changes in HDL size: either a PLTP-mediated decrease in HDL particle size, no change, or a PLTPmediated increase in HDL particle size [110, 111, 114, 115, 118]. The single study in the PLTP transgenic rabbit model showed that increased PLTP activity is associated with an increase in HDL size [112]. Also, PLTP activity has been shown to be significantly positively correlated to HDL size and HDL cholesterol among mouse strains [119].

The central question is: what all the results from this large number of animal studies really mean in terms of elucidation of the specific function of PLTP in human lipoprotein metabolism? It is clear that the impact of PLTP on lipoprotein metabolism depends significantly on the genetic background of the specific mouse model and the physiological context. Having absolutely no PLTP has a much different impact than having a reduced level of PLTP and having modest PLTP overexpression has a different impact than having a large excess of PLTP. Studies of PLTP knockout mice or mice with excessive expression of PLTP may have little relevance to normal lipoprotein physiology in mice or humans. Furthermore, mice, unlike humans, have no plasma CETP, have primarily HDL lipoproteins rather than apoB-containing lipoproteins, and the relative expression of other proteins and receptors involved in human lipoprotein metabolism differs from those in mice. It therefore must be recognized that these differences may limit the relevance of these studies to human lipoprotein metabolism. Because the decrease in apoB secretion in mice was only observed in the special physiological context of PLTP deficiency and excess apoB production, there is no basis to conclude that PLTP regulates apoB secretion under normal physiological conditions. However, it does appear, at least in the mouse, that PLTP plays an essential role in the transport of $\alpha$-tocopherol in vivo, and thereby can have a significant influence on the distribution of $\alpha$-tocopherol between the plasma compartment and tissues. In this context, a plausible mechanism for the putative regulation of apoB has been provided, as the vitamin $\mathrm{E}$ content of liver can modulate reactive oxygen species and these, in turn, could modulate the rate of apoB degradation Thus, further studies are warranted to evaluate the impact of PLTP 
expression on the modulation of vitamin E homeostasis and oxidative stress in vivo and its relevance to lipoprotein metabolism in humans.

The animal studies have shown that PLTP expression is required for normal HDL biogenesis, as PLTP plays an essential role in transport of surface lipids from apoBcontaining lipoproteins to nascent HDL. Excessive PLTP expression can lead to destabilization of HDL and enhanced degradation, but it is not clear that normal physiological variation in PLTP has a significant impact on HDL levels per se. As numerous in vitro studies have shown that PLTP can convert HDL particles into larger and smaller particles, it is reasonable to expect that differences in PLTP activity in the plasma compartment would have an impact on HDL size. However, the results from animal models have not provided a clear picture of the role of PLTP on the modulation of HDL size. The variable results are likely due to the variation in physiological context of each model, variation in the degree of PLTP expression, and the relative amount of apoB- and apoA-Icontaining particles expressed in a given animal model.

\section{PLTP and Atherosclerosis}

The findings from genetically engineered mouse models have, in general, strongly supported a role for PLTP in the development of atherosclerosis. This idea was initially promoted by studies of PLTP-deficient mice bred into apoB-transgenic and apoE-deficient backgrounds [107]. In both of these hyperlipidemic models, PLTP deficiency resulted in reduced production and levels of apoB-containing lipoproteins, and markedly reduced atherosclerosis. This concept was further supported by a series of studies in which human PLTP was introduced, using either a classic approach or an adenovirus-mediated system, in various mouse models of atherosclerosis. The models included mice heterozygous for the LDL receptor on high fat, high cholesterol diet [111], apoE-deficient mice [109], mice heterozygous for the LDL receptor expressing human CETP on an atherogenic diet [120], and LDL receptor-deficient mice with preexisting atherosclerosis [118]. The basis for increased atherosclerosis in these models included the fact that increased PLTP expression resulted in a dramatic reduction in HDL, a decrease in vitamin E content in lipoproteins and a consequent increase in lipoprotein oxidation, and presence of auto-antibodies against oxidized apoB-containing lipoproteins. PLTP-mediated phospholipid transfer activity was found to be essential for the increased atherogenesis in PLTP-transgenic mice as the overexpression of mutant PLTP lacking phospholipid transfer activity in an atherogenic mouse model failed to induce an increase in atherogenesis [121]. Consistent with these studies in mice, it was recently reported that human PLTP expression in transgenic rabbits results in increased atherosclerosis, when rabbits are exposed to a high fat, high cholesterol diet [112].

Although studies in mouse models suggest that excessive levels of PLTP in the systemic circulation promotes atherogenesis, a number of studies have suggested that PLTP expression in macrophages, or produced locally, is beneficial and atheroprotective. [91, 122-124]. For example, macrophage PLTP deficiency increases atherosclerosis in LDL receptor-deficient mice despite minimal changes in plasma cholesterol levels [122].

Macrophage PLTP deficiency in the apoE-deficient background promotes accumulation of cholesterol in the circulation and accelerates the development of atherosclerosis [91]. Bone marrow transplant from PLTP-deficient or wild type mice into the LDL receptor-deficient mice has shown that bone marrow-derived PLTP significantly decreased plasma cholesterol levels and increased HDL cholesterol, resulting in smaller atherosclerotic lesions in animals fed a high fat diet [123]. Furthermore, it was reported that systemic PLTP, but not macrophage PLTP, impairs macrophage reverse cholesterol transport in transgenic mice [124]. In contrast, another study reported that macrophage PLTP is a significant contributor to plasma PLTP activity, and that PLTP deficiency in macrophages leads to less 
atherosclerosis in LDL receptor-deficient mice on a high cholesterol diet [125]. Another study utilizing bone marrow transplant from either wild type, hemizygous or homozygous PLTP transgenic mice into LDL receptor-deficient mice resulted in mice with elevated expression of PLTP in the bone marrow-derived cells, increased atherosclerosis and nonHDL cholesterol, and decreased HDL cholesterol [126].

What can we conclude from these many studies regarding the role of PLTP in atherogenesis? Whether or not PLTP contributes to atherosclerosis in animals appears to depend on the genetic background and the physiological context, and requires the generation of a more atherogenic lipoprotein phenotype. Because mice are not susceptible to atherosclerosis, the mice are genetically modified to be either LDL receptor- or apoEdeficient. Furthermore, they are typically placed on a high fat, high cholesterol atherogenic diet to make them susceptible to atherosclerosis in a relatively short time. The functional properties of human PLTP could differ somewhat from mouse or rabbit PLTP in these in vivo models. Can we be confident to translate the findings obtained in animals with specialized genetic backgrounds and in an abnormal physiological context to humans? Before we answer that question, it may be instructive to review the literature regarding the studies to assess the role of LCAT in atherogenesis. Opposite conclusions regarding the atherogenic potential of LCAT were obtained when the same LCAT transgene was expressed in two different species, with LCAT over-expression in New Zealand rabbits resulting in marked protection against diet-induced atherosclerosis, while LCAT expression in mice resulted in enhanced atherosclerosis $[127,128]$. These results indicate that the genetic background and species can have a major impact on the outcome of a study and emphasize the importance of evaluating the atherogenic potential of PLTP in other animal species that are more likely to reflect human physiology. Thus, more studies in non-human primates and humans are needed before we can draw firm conclusions regarding the atherogenic potential of PLTP. In spite of these caveats, the results from the numerous mouse models and the single rabbit model do strongly suggest that markedly elevated expression of PLTP, particularly in the context of elevated apoB-containing lipoproteins, could contribute to atherosclerosis development. At the same time, the studies suggest that local PLTP production, such as by macrophages in the arterial wall, could be antiatherogenic, while elevation of systemic PLTP could be pro-atherogenic. Whether or not PLTP is beneficial or deleterious would likely depend on whether its production in a given tissue or cell type is at the right level for the physiological context and the genetic background. Thus, in general, PLTP performs essential functions and its production is beneficial, but too much or not enough of a good thing could be deleterious.

\section{PLTP and Signal Transduction}

PLTP-mediated lipid transfer between different lipoprotein particles, as well as between lipoproteins and cells, has been the central focus of PLTP research. Thus, most scientific investigations of PLTP have concentrated on PLTP functions in metabolism of plasma lipoproteins and in reverse cholesterol transfer by facilitating HDL-mediated cholesterol efflux. However, PLTP functions at the cellular level, particularly those that may be unrelated to its lipid transfer activity in the plasma compartment, have been largely neglected.

Seminal studies by Jack Oram on the interactions between apoA-I, HDL and ABCA1 on regulation of signal transduction were the impetus for our change of direction in PLTP research. His idea that ABCA1 acts not only as a lipid transporter, but also as a receptor, led to the collaborative studies intended to evaluate whether and how PLTP interaction with ABCA1 affects the ABCA1-dependent regulation of signal transduction. 
The initial studies have shown that both apoA-I and PLTP elicit ABCA1-dependent lipid efflux, but that the lipoprotein acceptor particles involved in the process are distinctly different. ApoA-I-dependent lipid efflux through ABCA1 requires presence of lipid-poor HDL particles, while PLTP-mediated lipid efflux through ABCA1 requires presence of mature HDL particles [77, 82]. Both PLTP and apoA-I appear to interact with ABCA1 in a similar manner and have similar effects on lipid efflux [77, 82; 84]. In collaborative studies with Jack Oram, we have shown that PLTP binds to ABCA1 and competitively inhibits apoA-I binding to ABCA1, suggesting that both proteins bind to the same or overlapping region of ABCA1 [82]. Furthermore, both PLTP and apoA-I stabilize ABCA1 [82]. ApoA-I binding stabilizes ABCA1 by inhibition of the calpain-dependent ABCA1 degradation through a mechanism that requires binding of PDZ-Rho guanine nucleotide exchange factor 11 and leukemia-associated Rho guanine nucleotide exchange factor 12, LARG, to the PDZ binding motif at the C-terminal of ABCA1 cytoplasmic domain and consequent activation of RhoA [129, 130]. While the exact mechanism responsible for PLTP-mediated stabilization of ABCA1 is currently unknown, the shared binding sites and similar effects on ABCA1dependent functions suggest that PLTP utilizes similar mechanisms for stabilization of ABCA1.

These initial findings raised numerous questions, including whether PLTP is capable of inducing other ABCA1-dependent effects that have been shown to be stimulated by apoA-I, such as activation of signal transduction. In the first study to implicate PLTP in cellular signaling we, in collaboration with Jack Oram and colleagues, reported that PLTP interaction with ABCA1 activates Janus kinase 2 (JAK2) in a manner similar to that induced by apoA-I [84]. While the PLTP region responsible for ABCA1-dependent lipid efflux has been reported [84], the structural determinants responsible for activation of signal transduction are currently unknown. Interestingly, a PLTP mutant with substitution of methionine (M159E/D) bound ABCA1 and induced JAK2 phosphorylation to greater extent than the wild-type, while having virtually no lipid transfer activity [84].

Our recent studies further expanded these initial findings, showing that both wild type PLTP and a PLTP mutant without lipid transfer activity activate STAT3 in macrophages. These studies indicate that PLTP-dependent regulation of the JAK2/STAT3 pathway is independent of PLTP-mediated, ABCA1-dependent lipid efflux. Consequently, both wild type and mutant PLTP significantly reduced secretion of pro-inflammatory markers and mediators into conditioned medium (unpublished data). ABCA1 inhibition using a chemical inhibitor in THP1 macrophages showed that PLTP-mediated activation of STAT3 is ABCA1-dependent (unpublished data). These findings are consistent with Jack Oram's conclusions that ABCA1 acts as an anti-inflammatory receptor in macrophages [131], and suggest that PLTP acts not only as a partner in the ABCA1-dependent cellular lipid efflux, a process critical for regulation of intracellular lipid content, but also affects regulation of cell signaling in a manner similar to that elicited by apoAI interaction with ABCA1 [84]. Interestingly, PLTP's pattern of expression is significantly different from other proteins in the same family, as well as from that of apolipoproteins, most of which have limited organ and cell type expression. It should be noted that plasma levels of PLTP are several orders of magnitude lower than those of apoA-I. However, PLTP levels are likely to be higher than apoA-I in tissues where apoA-I is not synthesized, such as in artery wall macrophages. These observations suggest that PLTP may be an important ABCA1 ligand in peripheral tissues.

Findings that the ability of PLTP to induce signal transduction through ABCA1 is not dependent on PLTP lipid transfer activity is of particular interest ([84] and unpublished data). PLTP mutant without lipid transfer activity activated the JAK2/STAT3 pathway comparative with that elicited by the wild type, indicating that PLTP functions extend 
beyond those dependent on lipid transfer. This finding may be physiologically relevant, since PLTP in human plasma is present in both lipid transfer-active and inactive forms [24-26]. While the exact nature of PLTP that is inactive in lipid transfer is not fully understood, the thriftiness of biological processes does not support the notion that inactive PLTP is merely a reservoir for the active form and raises the possibility that PLTP lacking lipid-transfer activity may be involved in the regulation of cell signaling.

We have recently obtained evidence that PLTP inhibits nuclear factor kappa B (NFkB) in human monocyte-derived macrophages and THP1 macrophages through the toll-like receptor-mediated pathway(s) (unpublished data). Regulation of the TLR-dependent pathways has been shown to be at least partially dependent on ABCA1, suggesting the possibility that PLTP may act through both ABCA1-dependent and independent mechanisms in the regulation of macrophage signal transduction. These novel findings strongly support the idea that PLTP acts as an anti-inflammatory agent in macrophages, and provide insight into potential mechanisms responsible for the observed anti-inflammatory actions of macrophage PLTP in vivo ([122, 123] and unpublished data).

Prompted by the findings that PLTP affects signal transduction in peripheral cells, we evaluated the possibility that PLTP regulates other, ABCA1-independent, signal transduction pathways. We have shown that PLTP modulates activity of at least two other signal transduction pathways in human neuronal cells, the PI3K/Akt/GSK3 $\beta$ and the Dab1dependent pathways [132]. PLTP-mediated activation of the PI3K/Akt pathway in human neuronal cells is dependent on the IR/IGFR kinase activity [132].

Physiological relevance of these findings is still under investigation, and has great potential to further our knowledge of the role of PLTP in human physiology and pathophysiology. Our studies raise fundamental questions about the role of PLTP in cellular metabolism, which require further study of mechanisms responsible for the observed PLTP-mediated regulation of signal transduction.

\section{PLTP in the Brain}

Jack Oram had many interests and projects he did not have a chance to develop. One of those was related to the role of PLTP and ABCA1 in the brain [133]. PLTP is expressed in the brain, and it is secreted by neurons and glial cells [22, 23]. Krapfenbauer and colleagues reported the presence of at least three PLTP isoforms in human brain [134]. PLTP is present and active in phospholipid transfer both in cerebrospinal fluid (CSF) and in brain tissue [23, 32, 135]. Animal and human studies have shown high levels of PLTP expression in choroid plexus and ependyma, suggesting that large portion of CSF PLTP is secreted by these structures, thus contributing to the CSF PLTP levels and activity [21, 30, 136]. However, relative contribution of the choroid plexus/ependyma and brain tissue to the PLTP levels in CSF is not known. Furthermore, the interplay between PLTP and ABCA1 in the brain has not been addressed.

A large proportion of the CSF PLTP is associated with apoE-containing lipoproteins [32]. ApoE is the main apolipoprotein in human brain, and there is a high correlation between PLTP activity and apoE in CSF $([32,137]$ and unpublished data). It should be noted that, unlike in plasma, CSF PLTP activity and protein levels are highly correlated, suggesting that virtually all of the CSF PLTP is active in lipid transfer. PLTP activity is positively correlated with amyloid precursor protein and microtubule-associated protein tau, markers of neurodegeneration, in CSF of cognitively normal adults. However these relationships were significantly attenuated when controlled for CSF apoE levels.[137]. Furthermore, PLTP regulates apoE expression and secretion in primary human astrocytes ([32] and unpublished data), suggesting an intricate regulatory mechanism for levels of apoE and 
PLTP in the brain. Given the complexity of apoE-mediated regulation of neuronal function through lipid delivery and regulation of signal transduction, these findings indicate a possibility that PLTP can indirectly modify these processes by regulation of apoE expression and secretion in the brain.

Significant differences in PLTP levels in different areas of the brain suggest specific PLTP functions in various brain regions ([23] and unpublished data). Immunohistochemical data have shown that PLTP is accumulated along the myelinated fibers in human brain [23], suggesting that it may play a role in maintenance of the functional and structural integrity of myelin. Our findings that CSF PLTP activity is reduced in active demyelinating disorders, while recovery correlates with increased CSF PLTP activity, support this notion [32]. Interestingly, PLTP expression in the brain is particularly high during brain development ([23] and unpublished data), further supporting its relevance for brain myelination.

Differential intracellular levels of PLTP in neurons associated with different pathways indicate the possibility that intracellular PLTP may play an important role in the brain. For example, neighboring neurons in Cornu Amonis (CA) layers 1 and 2 have significantly different intracellular PLTP levels [23], and published studies have shown that these neurons have significantly different sensitivity to oxidative damage and neurodegeneration due to their differential anti-oxidative potentials $[138,139]$. In lieu of known PLTP function in regulation of cell and tissue vitamin E content, it is possible that reduced PLTP expression in CA1 neurons is associated with the observed reduction of anti-oxidative potential in these neurons.

At the cellular level, PLTP regulates neuronal cell signaling through multiple signal transduction pathways [132]. In vitro studies have shown that PLTP reduces levels of both total Disabled-1 (Dab1) and Dab1 phosphorylated at tyrosine-232 and serine-491 $\left(\left(\mathrm{pDab}_{\text {Tyr232 }}\right.\right.$ and $\mathrm{pDab} 1_{\text {Ser491 }}$, respectively), suggesting that PLTP may be inhibiting activation of Dab1 in neurons [132]. It is unclear at this time which mechanism is responsible for the observed PLTP-mediated reduction in Dab1 levels and activity in human neuronal cells. Furthermore, PLTP reduces phosphorylation of microtubule-associated protein tau at residues phosphorylated by glycogen synthase kinase $3 \beta$ (GSK3 $\beta$ ). We have shown that PLTP inactivates GSK3 $\beta$ by inducing phosphorylation at serine-9 in GSK3 $\beta$ in human neuronal cells, which is dependent on activation of the phosphatidyl inositol-3 kinase (PI3K) and protein kinase B (PKB or Akt). Although the mechanism for the PLTP-mediated activation of the PI3K/Akt pathway is currently unknown, we have shown that the tyrosine kinase activity of the insulin receptor and insulin-like growth factor 1 receptor (IR/IGFR) is required for the observed PLTP-dependent regulation of this pathway.

Our studies suggest that PLTP plays multiple roles in the brain, including regulation of apoE and thus indirectly affecting numerous apoE-dependent processes in the brain, modulation of oxidative potential of the brain tissue, regulation or modification of cellular signal transduction pathways and is likely involved in maintenance of the myelin sheath. Given the incredible complexity of the human brain, these PLTP functions likely represent only a small portion of its functional repertoire in the brain. Physiological and pathophysiological relevance of these findings is still far from resolved.

\section{PLTP in Human Diseases}

PLTP mRNA, protein levels or activity are differentially regulated in numerous human diseases and conditions, including neurodegenerative and neuroinflammatory diseases, different types of cancer, diabetes and cardiovascular disease. However, the mechanisms through which PLTP may be regulating pathophysiological processes associated with these diseases are poorly understood, and whether changes in PLTP activity or levels are causative 
or consequential to the underlying pathophysiological processes in these diseases is either unknown or controversial.

Published studies support the notion that PLTP modulates inflammatory response in humans. PLTP activity in plasma is significantly increased in patients with sepsis, an uncontrolled systemic inflammatory response to microbial infection, compared to controls [33, 42]. Interestingly, an in vivo study has shown that PLTP deficiency is associated with the inability to fight bacterial infections, leading to severe sepsis and death [140]. Furthermore, our study in patients with periodontal disease suggests that increased plasma PLTP activity is associated with a lower level of tissue damage in bacterial infection, suggesting its involvement in the resolution of an inflammatory process [141]. Combined, these studies indicate that an increase in plasma PLTP activity is an important compensatory mechanism for the regulation of an inflammatory response, and suggest that a reduction in plasma PLTP activity in patients with sepsis may be an ominous prognostic sign.

Cerebrospinal fluid PLTP activity is significantly reduced in active neuroinflammatory diseases, such as multiple sclerosis, and increases as the inflammatory process becomes inactive ([32] and unpublished data). Thus, it appears that in patients with multiple sclerosis CSF PLTP activity could be a sensitive marker for remyelination. Neurodegenerative diseases, such as Alzheimer's disease, are also associated with significantly lower CSF PLTP activity compared to healthy controls ([23, 32] and unpublished data). In neurodegeneration, there are at least two different mechanisms that might explain the CSF PLTP activity reduction. In the early stage of a neurodegenerative process, PLTP levels increase in the brain tissue and decrease in CSF [23, 32]. A small study in a Japanese population suggested that mutations in the PLTP gene are not associated with the risk of Alzheimer's disease [142]. We hypothesize that the increase of PLTP in brain tissue during the early phase of neurodegeneration is a result of significant changes in cell function and extracellular matrix, leading to PLTP retention in this tissue. In contrast, the reduction in PLTP levels and activity occurs in both the tissue and the CSF in the late stage of the neurodegenerative process, and is likely a result of significant cell death that overcomes the brain compensatory mechanisms [23].

Several studies have shown that plasma PLTP plays an important role in regulation of vitamin E levels in plasma and in tissues. While PLTP deficiency results in increased antioxidative potential of circulating lipoprotein particles due to retention of $\alpha$-tocopherol in the intravascular compartment, this rise in lipoprotein anti-oxidative potential was accomplished at the expense of cells and tissues, significantly reducing their anti-oxidative potential [108, 143]. PLTP deficiency significantly reduced brain tissue $\alpha$-tocopherol levels in vivo, and was associated with an increase in anxiety symptoms [143]. Interestingly, a mutation in PLTP gene (M154R), which significantly reduced plasma PLTP lipid transfer activity despite normal protein levels, has been associated with ataxia due to reduced brain vitamin $\mathrm{E}$ levels in humans [144]. These studies suggest that PLTP is one of the main regulators of the brain vitamin E content in vivo. While it is reasonable to hypothesize that PLTP activity in plasma, CSF and brain tissue is associated with significant differences in the brain levels of vitamin $\mathrm{E}$ in humans, functional significance of variations in PLTP activity on the brain $\alpha-$ tocopherol content has not been established. Based on the findings of the in vivo studies, it is tantalizing to speculate that the interplay between plasma PLTP and the brain vitamin E content may be relevant in at least some forms of anxiety in humans.

PLTP is differentially expressed in acute and chronic leukemia, glioblastoma, pleomorphic liposarcoma, adenomas, lung, prostate, breast and other cancers, and the region on chromosome 20 that encodes for PLTP, 20q12-13.1 [6], has been associated with leukemia and other cancers ([145-152] and data obtained through online data-mining). Furthermore, 
computer modeling suggests that PLTP is one of the determining factors in the regulation of survival in breast cancer patients [153], and PLTP is part of a small group of genes whose methylation pattern differentiates between two types of breast cancer [154]. Such a wide range of cancer types with differentially expressed PLTP suggests the possibility that PLTP is a significant regulator of some common process associated with neoplasia. Our recent findings that PLTP regulates signal transduction through the PI3K/Akt pathway [132, 155], that secreted PLTP re-enters the cells, and that PLTP translocates to the nucleus where it maintains its lipid transfer activity [156], suggest some potential mechanisms that may be involved in PLTP-dependent modification of processes associated with cancer development. However, much more work is needed to fully delineate the mechanisms of PLTP functions at the cellular level that may be associated with neoplastic processes.

PLTP activity in plasma appears to be strongly influenced by body weight, in particular with subcutaneous fat $[56,157,158]$. However, the impact of insulin resistance on plasma PLTP activity in non-diabetic humans is unclear $[157,158]$. In patients with diabetes, PLTP activity in plasma is significantly increased compared to healthy controls. Multiple regression analysis suggests that plasma PLTP activity is positively and independently associated with carotid intima-media thickness in patients with type 2 diabetes [159]. These findings are often interpreted as proofs of causal relationship between elevated plasma PLTP activity and diabetes and its complications, such as carotid artery disease. Attia et al. reported that cells isolated from patients with type 2 diabetes have impaired cholesterol efflux [1609]. However, De Vries et al. reported that efflux from cultured fibroblasts to plasma obtained from type 2 diabetes patients is either normal, or enhanced due to an increase in PLTP activity [161], while efflux to plasma obtained from type 1 diabetes patients was enhanced by PLTP [162]. These findings suggest that the impairment in cellular cholesterol efflux reported in some type 2 diabetes patients is cell- or systemrelated, rather than PLTP-related. The functional impairment in cellular cholesterol efflux in type 2 diabetes could prompt cells to secrete more PLTP in an attempt to rectify the disorder, since PLTP enhances lipid efflux from cells via an ABCA1-dependent mechanism $[77,82,84]$. Tang et al. reported that diabetes is associated with a significant reduction in ABCA1 protein levels in macrophages and kidneys in vivo [163], and patients with diabetes often have low HDL and apoA-I levels. Combination of these factors would contribute to a net decrease of cellular lipid efflux in type 2 diabetes despite the increase in plasma PLTP activity. Thus, the observed increase of plasma PLTP activity in diabetes may represent a compensatory response.

\section{Summary}

Research efforts to understand the physiological and pathophysiological roles of PLTP have steadily increased since its discovery. Despite the abundance of data regarding PLTP's transport functions, existing controversies and the relative paucity of data related to PLTPcell interactions and its contributions to pathogenesis of human diseases continue to stimulate interest in this protein. Jack Oram's contributions to this field of research will have a lasting impact on future research into PLTP's functions in health and disease.

\section{Acknowledgments}

We are grateful to Dr. Gertrud Wolfbauer, whose work over the years provided many of the data mentioned in this review. We also thank Dr. Chongren Tang for critical reading of portions of our manuscript. 


\section{References}

1. Day JR, Albers JJ, Lofton-Day CE, Gilbert TL, Ching AF, Grant FJ, O'Hara PJ, Marcovina SM, Adolphson JL. Complete cDNA encoding human phospholipid transfer protein from human endothelial cells. J Biol Chem. 1994; 269:9388-9391. [PubMed: 8132678]

2. Tu AY, Deeb SS, Iwasaki L, Day JR, Albers JJ. Organization of human phospholipid transfer protein gene. Biochem Biophys Res Comm. 1995; 207:552-558. [PubMed: 7864842]

3. Kirschning CJ, Au-Young J, Lamping N, Reuter D, Pfeil D, Seilhamer JJ, Schumann RR. Similar organization of the lipopolysaccharide-binding protein (LBP) and phospholipid transfer protein (PLTP) genes suggests a common gene family of lipid-binding proteins. Genomics. 1997; 46:416425. [PubMed: 9441745]

4. Hailman E, Albers JJ, Wolfbauer G, Tu AY, Wright SD. Neutralization and transfer of lipopolysaccharide by phospholipid transfer protein. J Biol Chem. 1996; 271:12172-12473. [PubMed: 8647810]

5. Bruce C, Beamer LJ, Tall AR. The implications of the structure of the bactericidal/permeabilityincreasing protein on the lipid-transfer function of the cholesteryl ester transfer protein. Curr Opin Struct Biol. 1998; 8:426-434. [PubMed: 9729732]

6. Whitmore TE, Day JR, Albers JJ. Localization of the human phospholipid transfer protein gene to chromosome 20q12-q13.1. Genomics. 1995; 28:599-600. [PubMed: 7490104]

7. Bouly M, Masson D, Gross B, Jiang XC, Fievet C, Castro G, Tall AR, Fruchart JC, Staels B, Lagrost L, Luc G. Induction of the phospholipid transfer protein gene accounts for the high density lipoprotein enlargement in mice treated with fenofibrate. J Biol Chem. 2001; 276:25841-25847. [PubMed: 11342537]

8. Tu AY, Albers JJ. Glucose regulates the transcription of human genes relevant to HDL metabolism: responsive elements for peroxisome proliferator-activated receptor are involved in the regulation of phospholipid transfer protein. Diabetes. 2001; 50:1851-1856. [PubMed: 11473048]

9. Tu AY, Albers JJ. Functional analysis of the transcriptional activity of the mouse phospholipid transfer protein gene. Biochem, Biophys Res Commun. 2001; 287:921-926. [PubMed: 11573953]

10. Albers JJ, Day JR, Wolfbauer G, Kennedy H, Vuletic S, Cheung MC. Impact of site-specific Nglycosylation on cellular secretion, activity and specific activity of the plasma phospholipid transfer protein. Biochim Biophys Acta. 2011; 1814:908-911. [PubMed: 21515415]

11. Beamer LJ, Carrol SF, Eisenberg D. Crystal structure of human BPI and two bound phospholipids at 2.4 angstrom resolution. Science. 1997; 276:18661-1864.

12. Tall AR, Abreu E, Shuman J. Separation of a plasma phospholipid transfer protein from cholesterol ester/phospholipid exchange protein. J Biol Chem. 1983; 258:2174-2180. [PubMed: 6822552]

13. Albers JJ, Tollefson JH, Chen CH, Steinmetz A. Isolation and characterization of human plasma lipid transfer protein. Arteriosclerosis. 1984; 4:49-58. [PubMed: 6691846]

14. Tollefson JH, Ravnik S, Albers JJ. Isolation and characterization of a phospholipid transfer protein (LTP-II) from human plasma. J Lipid Res. 1988; 29:1593-1602. [PubMed: 2854151]

15. Nishida HI, Klock DG, Guo Z, Ykstys BP, Nishida T. Phospholipid transfer protein can transform reconstituted discoidal HDL into vesicular structures. Biochim Biophys Acta. 1997; 1349:222232. [PubMed: 9434136]

16. Rao R, Albers JJ, Wolfbauer G, Pownall HJ. Molecular and macromolecular specificity of human plasma phospholipid transfer protein. Biochemistry. 1997; 36:3645-3653. [PubMed: 9132017]

17. Kostner GM, Oetti K, Jauhiainen M, Ehnholm C, Esterbauer H, Dieplinger H. Human plasma phospholipid transfer protein accelerates exchange/transfer of alpha-tocopherol between lipoproteins and cells. Biochem J. 1995; 305:659-667. [PubMed: 7832785]

18. Desrumaux C, Deckert V, Athias A, Masson D, Lizard G, Palleau V, Gambert P, Lagrost L. Plasma phospholipid transfer protein prevents vascular endothelium dysfunction by delivering alpha-tocopherol to endothelial cells. FASEB J. 1999; 13:883-892. [PubMed: 10224231]

19. Klein A, Deckert V, Schneider M, Dutrillaux F, Hammann A, Athias A, La Guern N, Pais de Barros JP, Desrumaux C, Masson D, Jiang XC, Lagrost L. Alpha-tocopherol modulates 
phosphatidylserine externalization in erythrocytes: relevance in phospholipid transfer proteindeficient mice. Arterioscler Thromb Vasc Biol. 2006; 26:2160-2167. [PubMed: 16825594]

20. Oslakovic C, Jauhiainen M, Ehnholm C, Dahlbäck B. The role of phospholipid transfer protein in lipoprotein-mediated neutralization of the procoagulant effect of anionic liposomes. J Thromb Haemost. 2010; 8:766-772. [PubMed: 20088939]

21. Oslakovic C, Krisinger MJ, Andersson A, Jauhiainen M, Ehnholm C, Dahlbäck B. Anioninc phospholipids lose their procoagulant properties when incorporated into high density lipoproteins. J Biol Chem. 2009; 284:5896-5904. [PubMed: 19129179]

22. Albers JJ, Wolfbauer G, Cheung MC, Day JR, Ching AFT, Lock S, Tu AY. Functional expression of human and mouse plasma phospholipid transfer protein: effect of recombinant and plasma PLTP on HDL subspecies. Biochim Biophys Acta. 1995; 1258:27-34. [PubMed: 7654777]

23. Vuletic S, Jin LW, Marcovina SM, Peskind ER, Möller T, Albers JJ. Widespread distribution of phospholipid transfer protein (PLTP) in human central nervous system: evidence for PLTP synthesis by glia and neurons and for increased levels in Alzheimer's disease. J Lipid Res. 2003; 44:1113-1123. [PubMed: 12671035]

24. Oka T, Kujiraoka T, Ito M, Egashira T, Takahashi S, Nanjee MN, Miller NE, Metso J, Olkkonen VM, Ehnholm C, Jauhiainen M, Hattori H. Distribution of phospholipid transfer protein in human plasma: presence of two forms of phospholipid transfer protein, one catalytically active and the other inactive. J Lipid Res. 2000; 41:1651-1657. [PubMed: 11013307]

25. Kärkkäinen M, Oka T, Olkkonen VM, Metso J, Hattori H, Jauhiainen M, Ehnholm C. Isolation and partial characterization of the inactive and active forms of human plasma phospholipid transfer protein (PLTP). J Biol Chem. 2002; 277:15413-15418. [PubMed: 11854286]

26. Murdoch SJ, Wolfbauer G, Kennedy H, Marcovina SM, Carr MC, Albers JJ. Differences in reactivity of antibodies to active versus inactive PLTP significantly impact PLTP measurement. J Lipid Res. 2002; 43:281-289. [PubMed: 11861670]

27. Jänis MT, Siggins S, Tahvanainen E, Vikstedt R, Silander K, Metso J, Aromaa A, Taskinen MR, Olkkonen VM, Jauhiainen M, Ehnholm C. Active and low-active forms of serum phospholipid transfer protein in a normal Finnish population sample. J Lipid Res. 2004; 45:2303-2309. [PubMed: 15342679]

28. Cheung MC, Wolfbauer G, Albers JJ. Different phospholipid transfer protein complexes contribute to the variation in plasma PLTP specific activity. Biochim Biophys Acta. 2011; 1811:343-347. [PubMed: 21303701]

29. Oka T, Yamashita S, Kujiraoka T, Ito M, Nagano M, Sagehashi Y, Egashira T, Nanjee MN, Hirano K-I, Miller NE, Matsuzawa Y, Hattori H. Distribution of human plasma PLTP mass and activity in hypo- and hyperalphalipoprotienemia. J Lipid Res. 2002; 43:1236-1243. [PubMed: 12177167]

30. Jauhiainen M, Setälä NL, Ehnholm C, Metso J, Tervo TM, Eriksson O, Lolopainen JM. Phospholipid transfer protein is present in human tear fluid. Biochemistry. 2005; 44:8111-8116. [PubMed: 15924430]

31. Siggins S, Jauhiainen M, Olkkonen VM, Tenhunen J, Ehnholm C. PLTP secreted by HepG2 cells resembles the high-activity PLTP form in human plasma. J. Lipid Res. 2003; 44:1698-1704. [PubMed: 12810820]

32. Vuletic S, Peskind ER, Marcovina SM, Quinn JF, Cheung MC, Kennedy H, Kaye JA, Jin LW, Albers JJ. Reduced CSF PLTP activity in Alzheimer's disease and other neurologic conditions; PLTP induces apoE secretion in primary human astrocytes in vitro. J Neurosci Res. 2005; 80:406413. [PubMed: 15795933]

33. Barlage S, Frohlich D, Bottcher A, Jauhiainen M, Muller HP, Noetzel F, Rothe G, Schutt C, Linke RP, Lackner KJ, Ehnholm C, Schmitz G. ApoE-containing high density lipoproteins and phospholipid transfer protein activity increase in patients with a systemic inflammatory response. $\mathrm{J}$ Lipid Res. 2001; 42:281-290. [PubMed: 11181759]

34. Pussinen PJ, Metso J, Malle E, Barlage S, Palosuo T, Sattler W, Schmitz G, Jauhiainen M. The role of plasma phospholipid transfer protein (PLTP) in HDL remodeling in acute-phase patients. Biochim Biophys Acta. 2001; 1533:153-163. [PubMed: 11566452]

35. Kujiraoka T, Nanjee MN, Oka T, Ito M, Nagano M, Cooke CJ, Takahashi S, Olszewski WL, Wong JS, Stepanova IP, Hamilton RL, Egashira T, Hattori H, Miller NE. Effects of intravenous 
apolipoprotein A-I/phosphatidylcholine discs on LCAT, PLTP, and CETP in plasma and peripheral lymph in humans. Arterioscler Thromb Vasc Biol. 2003; 23:1653-1659. [PubMed: 12893687]

36. Pussinen PJ, Jauhiainen M, Vilkuna-Rautiainen T, Sundvall J, Vesanen M, Mattila K, Palosuo T, Alfthan G, Asikainen S. Periodontitis decrease the antiatherogenic potency of high density lipoprotein. J Lipid Res. 2004; 45:139-147. [PubMed: 13130123]

37. Cheung MC, Albers JJ. Active plasma phospholipid transfer protein is associated with apoA-I- but not apoE-containing lipoproteins. J Lipid Res. 2006; 47:1315-1321. [PubMed: 16520487]

38. Jänis MT, Metso J, Lankinen H, Strandin T, Olkkonen VM, Rye KA, Jauhiainen M, Ehnholm C. Apolipoprotein E activates the low-activity form of human phospholipid transfer protein. Biochem Biophys Res Commun. 2005; 331:333-340. [PubMed: 15845396]

39. Vikstedt R, Metso J, Hakala J, Olkkonen VM, Ehnholm C, Jauhiainen M. Cholesterol efflux from macrophage foam cells is enhanced by active phospholipid transfer protein through generation of two types of acceptor particles. Biochemistry. 2007; 46:11979-11986. [PubMed: 17900150]

40. Setala NL, Holopainen JM, Metso J, Wiedmer SK, Yohannes G, Kinnunen PKJ, Ehnholm C, Jauhiainen M. Interfacial and lipid transfer properties of human phospholipid transfer protein: Implications for the transfer mechanism of phospholipids. Biochemistry. 2007; 46:1312-1319. [PubMed: 17260960]

41. Cheung MC, Vaisar T, Han X, Heinecke JW, Albers JJ. Phospholipid transfer protein in human plasma associates with proteins linked to immunity and inflammation. Biochemistry. 2010; 49:7314-7322. [PubMed: 20666409]

42. Levels JH, Pajkrt D, Schultz M, Hoek FJ, van Tol A, Meijers JC, van Deventer SJ. Alterations in lipoprotein homeostasis during human experimental endotoxemia and clinical sepsis. Biochim Biophys Acta. 2007; 1771:1429-1438. [PubMed: 17980169]

43. Albers JJ, Cheung MC. Emerging roles for phospholipid transfer protein in lipid and lipoprotein metabolism. Curr Opin Lipidol. 2004; 15:255-260. [PubMed: 15166780]

44. Desrumaux CM, Mak PA, Boisvert WA, Masson D, Stupack D, Jauhiainen M, Ehnholm C, Curtiss LK. Phospholipid transfer protein is present in human atherosclerotic lesions and is expressed by macrophages and foam cells. J Lipid Res. 2003; 44:1453-1461. [PubMed: 12730304]

45. O'Brien KD, Vuletic S, McDonald TO, Wolfbauer G, Lewis K, Tu AY, Marcovina S, Wight TN, Chait A, Albers JJ. Cell-associated and extracellular phospholipid transfer protein in human coronary atherosclerosis. Circulation. 2003; 108:270-274. [PubMed: 12835223]

46. Cheung MC, Wolfbauer G, Albers JJ. Plasma phospholipid mass transfer rate: relationship to plasma phospholipid and cholesteryl ester transfer activities and lipid parameters. Biochim Biophys Acta. 1996; 1303:103-110. [PubMed: 8856039]

47. Settasatian N, Duong M, Curtiss LK, Ehnholm C, Jauhiainen M, Huuskonen J, Rye K-A. The mechanism of the remodeling of high density lipoproteins by phospholipid transfer protein. J Biol Chem. 2001; 276:26898-26905. [PubMed: 11325961]

48. Desrumaux C, Athias A, Bessede G, Verges B, Farnier M, Persegol L, Gambert P, Lagrost L. Mass concentration of plasma phospholipid transfer protein in normolipidemic, type IIa hyperlipidemic, type IIb hyperlipidemic, and non-insulin-dependent diabetic subjects as measured by a specific ELISA. Arterioscler Thromb Vasc Biol. 1999; 19:266-275. [PubMed: 9974406]

49. Tahvanainen E, Jauhiainen M, Funke H, Vartiainen E, Sundvall J, Ehnholm C. Serum phospholipid transfer protein activity and genetic variation of the PLTP gene. Atherosclerosis. 1999:107-115. [PubMed: 10487493]

50. Oka T, Kujiraoka T, Ito M, Nagano M, Ishihara M, Iwasaki T, Egashira T, Miller NE, Hattori H. Measurement of human plasma phospholipid transfer protein by sandwich ELISA. Clin Chem. 2000; 46:1357-1364. [PubMed: 10973866]

51. Cheung MC, Wolfbauer G, Deguchi H, Fernandez JA, Griffin JH, Albers JJ. Human plasma phospholipid transfer protein specific activity is correlated with HDL size: Implications for lipoprotein physiology. Biochim Biophys Acta. 1791(2009):206-211. [PubMed: 19162221]

52. Cheung MC, Knopp RH, Retzlaff B, Kennedy H, Wolfbauer G, Albers JJ. Association of plasma phospholipid transfer protein activity with IDL and buoyant LDL: impact of gender and adiposity. Biochim Biophys Acta. 2002; 1587:53-59. [PubMed: 12009424] 
53. Tan KCB, Shiu SWM, Wong Y, Wong WK, Tam S. Plasma apolipoprotein E concentration is an important determinant of phospholipid transfer protein activity in type 2 diabetes mellitus. Diabetes Metab Res Rev. 2006; 22:307-312. [PubMed: 16389649]

54. Dullaart RP, Sluiter WJ, Dikkeschei LD, Hoogenberg K, Van Tol A. Effect of adiposity on plasma lipid transfer protein activities: a possible link between insulin resistance and high density lipoprotein metabolism. Eur J Clin Invest. 1994; 24:188-94. [PubMed: 8033953]

55. Kaser S, Sandhofer A, Foger B, Ebenbichler CF, Igelseder B, Malaimare L, Paulweber B, Patsch JR. Influence of obesity and insulin sensitivity on phospholipid transfer protein activity. Diabetologia. 2001; 44:1111-1117. [PubMed: 11596664]

56. Murdoch SJ, Carr MC, Hokanson JE, Brunzell JD, Albers JJ. PLTP activity in premenopausal women. Relationship with lipoprotein lipase, HDL, LDL, body fat, and insulin resistance. J Lipid Res. 2000; 41:237-244. [PubMed: 10681407]

57. Cheung MC, Brown BG, Marino Larsen EK, Frutkin AD, O'Brien KD, Albers JJ. Phospholipid transfer protein activity is associated with inflammatory markers in patients with cardiovascular disease. Biochim Biophys Acta. 2005; 1762:131-137. [PubMed: 16216472]

58. Colhoun HM, Taskinen MR, Otvos JD, Van Den Berg P, O'Connor J, Van Tol A. Relationship of phospholipid transfer protein activity to HDL and apolipoprotein B-containing lipoproteins in subjects with and without type 1 diabetes. Diabetes. 2002; 51:3300-3305. [PubMed: 12401722]

59. Riemens S, van Tol A, Sluiter W, Dullaart R. Elevated plasma cholesteryl ester transfer in NIDDM: relationships with apolipoprotein B-containing lipoproteins and phospholipid transfer protein. Atherosclerosis. 1998; 140:71-79. [PubMed: 9733217]

60. Tan KCB, Shiu SWM, Wong Y, Tam S. Plasma phospholipid transfer protein activity and subclinical inflammation in type 2 diabetes mellitus. Atherosclerosis. 2005; 178:365-370. [PubMed: 15754464]

61. Huuskonen J, Ekstrom M, Tahvanainen E, Vainio A, Metso J, Pussinen P, Ehnholm C, Olkkonen VM, Jauhiainen M. Quantification of human plasma phospholipid transfer protein (PLTP): relationship between PLTP mass and phospholipid transfer activity. Atherosclerosis. 2000; 151:451-461. [PubMed: 10924722]

62. Cheung MC, Sibley SD, Palmer JP, Oram JF, Brunzell JD. Lipoprotein lipase and hepatic lipase: their relationship with HDL subspecies Lp(A-I and Lp(A-I,A-II). J Lipid Res. 2003; 44:15521558. [PubMed: 12777470]

63. Yatsuya H, Tamakoshi K, Hattori H, Otsuka R, Wada K, Zhang H, Mabuchi T, Ishikawa M, Murata C, Yoshida T, Kondo T, Toyoshima H. Serum phospholipid transfer protein mass as a possible protective factor for coronary heart diseases. Circ J. 2004; 68:11-16. [PubMed: 14695459]

64. Dullaart RP, De Vries R, Scheek L, Borggreve SE, Van Gent T, Dallinga-Thie GM, Ito M, Nagano M, Sluiter WJ, Hattori H, Van Tol A. Type 2 diabetes mellitus is associated with differential effects on plasma cholesteryl ester transfer protein and phospholipid transfer protein activities and concentrations. Scand J Clin Lab Invest. 2004; 64:205-15. [PubMed: 15222630]

65. Siggins S, Karkkainen M, Tenhunen J, Metso J, Tahvanainen E, Olkkonen VM, Jauhiainen M, Ehnholm C. Quantitation of the active and low-active forms of human plasma phospholipid transfer protein by ELISA. J Lipid Res. 2004; 45:387-395. [PubMed: 14617737]

66. Tall AR, Krumholz S, Olivecrona T, Deckelbaum RJ. Plasma phospholipid transfer protein enhances transfer and exchange of phospholipids between very low density lipoproteins and high density lipoproteins during lipolysis. J Lipid Res. 1985; 26:842-851. [PubMed: 4031662]

67. Bailey D, Ruel I, Mafinae A, Cochrane H, Iatan I, Jauhiainen M, Ehnholm C, Krimbou L, Genest J. Analysis of lipid transfer activity between model nascent HDL particles and plasma lipoproteins: implications for current concepts of nascent HDL maturation and genesis. J Lipid Res. 2010; 51:785-797. [PubMed: 19797257]

68. Rye KA, Barter PJ. Changes in the size and density of human high-density lipoproteins promoted by a plasma-conversion factor. Biochim Biophys Acta. 1988; 875:429-438. [PubMed: 3947651]

69. Jauhiainen M, Metso J, Pahlman R, Blomqvist S, van Tol A, Ehnholm C. Human plasma phospholipid transfer protein causes high density lipoprotein conversion. J Biol Chem. 1993; 268:4032-4036. [PubMed: 8440695] 
70. Tu AY, Nishida HI, Nishida T. High density lipoprotein conversion mediated by human plasma phospholipid transfer protein. J Biol Chem. 1993; 268:23098-23105. [PubMed: 8226827]

71. Lusa S, Jauhiainen M, Metso J, Somerharju P, Ehnholm C. The mechanism of human plasma phospholipid transfer protein-induced enlargement of high-density lipoprotein particles: evidence for particle fusion. Biochem J. 1996; 313:275-282. [PubMed: 8546695]

72. Lagrost L. The role of cholesteryl ester transfer protein and phospholipid transfer protein in the remodeling of plasma high-density lipoproteins. Trends Cardiovasc Med. 1997; 7:218-224. [PubMed: 21235888]

73. Marques-Vidal P, Jauhiainen M, Metso J, Ehnholm C. Transformation of high density lipoprotein 2 particles by hepatic lipase and phospholipid transfer protein. Atherosclerosis. 1997; 133:87-95. [PubMed: 9258411]

74. Nishida NI, Klock DG, Guo Z, Jakstys BP, Nishida T. Phospholipid transfer protein can transform reconstituted discoidal HDL into vesicular structures. Biochim Biophys Acta. 1997; 1349:222232. [PubMed: 9434136]

75. Huuskonen J, Olkkonen VM, Ehnholm C, Metso J, Julkunen I, Jauhiainen M. Phospholipid transfer is a prerequisite for PLTP-mediated HDL conversion. Biochemistry. 2000; 39:1609216098. [PubMed: 11123937]

76. Pussinen PJ, Jauhiainen M, Ehnholm C. ApoA-II/apoA-I molar ratio in the HDL particle influences phospholipid transfer protein-mediated HDL interconversion. J Lipid Res. 1997; 38:1221. [PubMed: 9034196]

77. Wolfbauer G, Albers JJ, Oram JF. Phospholipid transfer protein enhances removal of cellular cholesterol and phospholipids by high-density lipoprotein apolipoproteins. Biochim Biophys Acta. 1999; 1439:65-76. [PubMed: 10395966]

78. Pussinen P, Jauhiainen M, Meso J, Tyynelä J, Ehnholm C. Pig plasma phospholipid transfer protein facilitates HDL interconversion. J Lipid Res. 1995; 36:975-985. [PubMed: 7658169]

79. von Eckardstein A, Jauhiainen M, Huang Y, Metso J, Langer C, Pussinen P, Wu S, Ehnholm C, Assmann G. Phospholipid transfer protein mediated conversion of high density lipoproteins generates pre beta 1-HDL. Biochim Biophys Acta. 1996; 1301:255-262. [PubMed: 8664337]

80. Castro GR, Fielding CJ. Early incorporation of cell-derived cholesterol into pre-beta-migrating high-density lipoprotein. Biochemistry. 1988; 27:25-29. [PubMed: 3126809]

81. Laffitte BA, Joseph SB, Chen M, Castrillo A, Repa J, Wilpitz D, Mangelsdorf D, Tonotonoz P. The phospholipid transfer protein gene is a liver $\mathrm{X}$ receptor target expressed by macrophages in atherosclerotic lesions. Mol Cell Biol. 2003; 23:2182-2191. [PubMed: 12612088]

82. Oram JF, Wolfbauer G, Vaughan AM, Tang C, Albers JJ. Phospholipid transfer protein interacts with and stabilizes ATP-binding cassette transporter A1 and enhances cholesterol efflux from cells. J Biol Chem. 2003; 278:52379-52385. [PubMed: 14559902]

83. Vaughan AM, Oram JF. ABCA1 redistributes membrane cholesterol independent of apolipoprotein interactions. J Lipid Res. 2003; 44:1373-1380. [PubMed: 12700343]

84. Oram JF, Wolfbauer G, Tang C, Davidson WS, Albers JJ. An amphipathic helical region of the Nterminal barrel of phospholipid transfer protein is critical for ABCA1-dependent cholesterol efflux. J Biol Chem. 2008; 283:11541-11549. [PubMed: 18287097]

85. Lee-Rueckert M, Vikstedt R, Metso J, Ehnholm C, Kovanen PT, Jauhiainen M. Absence of endogenous phospholipid transfer protein impairs ABCA1-dependent efflux of cholesterol from macrophage foam cells. J Lipid Res. 2006; 47:1725-1732. [PubMed: 16687660]

86. Tang C, Oram JR. The cell cholesterol exporter ABCA1 as a protector from cardiovascular disease and diabetes. Biochim Biophys Acta. 2009; 1791:563-572. [PubMed: 19344785]

87. Kennedy MA, Venkaterswaran A, Tarr PT, Xenarios I, Kudoh J, Shimizu N, Edwards PA. Characterization of the human ABCG1 gene: liver $\mathrm{X}$ receptor activates an internal promoter that produces a novel transcript encoding an alternative form of the protein. J Biol Chem. 2001; 276:39438-39447. [PubMed: 11500512]

88. Laffitte BA, Repa JJ, Joseph SB, Wilpitz DC, Kast HR, Mangelsdorf DJ, Tontonoz P. LXRs control lipid-inducible expression of the apolipoprotein E gene in macrophages and adipocytes. Proc Natl Acad Sci USA. 2001; 98:507-512. [PubMed: 11149950] 
89. Mak PA, Kast-Woelbern HR, Anisfeld AM, Edwards PA. Identification of PLTP as an LXR target gene and apoE as an FXR target gene reveals overlapping targets for the two nuclear receptors. J Lipid Res. 2002; 43:2037-2041. [PubMed: 12454263]

90. Cao G, Beyer TP, Yang XP, Schmidt RJ, Zhang Y, Bersch WR, Kauffman RF, Gao H, Ryan TP, Liang Y, Eacho PI, Jiang XC. Phospholipid transfer protein is regulated by liver X receptors in vivo. J Biol Chem. 2002; 277:39561-39565. [PubMed: 12177004]

91. Liu R, Hojjati MR, Devlin CM, Hansen IH, Jiang XC. Macrophage phospholipid transfer protein deficiency and apoE secretion: impact on mouse plasma cholesterol levels and atherosclerosis. Arterioscler Thromb Vasc Biol. 2007; 27:190-196. [PubMed: 17038631]

92. Langer C, Huang Y, Cullen P, Wiesenhütter B, Mahley RW, Assmann G, von Eckardstein A. Endogenous apolipoprotein E modulates cholesterol efflux and cholesteryl ester hydrolysis mediated by high-density lipoprotein-3 and lipid-free apolipoproteins in mouse peritoneal macrophages. J Mol Med. 2000; 78:217-227. [PubMed: 10933584]

93. Hayek T, Oiknine J, Brook JG, Aviram M. Role of HDL apolipoprotein E in cellular cholesterol efflux: studies in apoE knockout transgenic mice. Biochem Biophys Res Commun. 1994; 305:1072-1078. [PubMed: 7802634]

94. Zanotti I, Pedrelli M, Poti F, Stomeo G, Gomaraschi M, Calabresi L, Bernini F. Macrophage, but not systemic, apolipoprotein $\mathrm{E}$ is necessary for macrophage reverse cholesterol transport in vivo. Arterioscler Thromb Vasc Biol. 2011; 31:74-80. [PubMed: 20966401]

95. Spirin V, Schmidt S, Pertsemlidis A, Cooper RS, Cohen JC, Sunyaev SR. Common singlenucleotide polymorphisms act in concert to affect plasma levels of high-density lipoprotein cholesterol. Am J Hum Genet. 2007; 81:1298-1303. [PubMed: 17952847]

96. Aouizerat BE, Engler MB, Natanzon Y, Kulkarni M, Song J, Eng C, Huuskonen J, Rivera C, Poon A, Bensley M, Sehnert A, Zellner C, Malloy M, Kane J, Pullinger CR. Genetic variation of PLTP modulates lipoprotein profiles in hypoalphalipoproteinemia. J Lipid Res. 2006; 47:787-793. [PubMed: 16388083]

97. Engler MB, Pullinger CR, Malloy MJ, Natanzon Y, Kulkarni MV, Song J, Eng C, Huuskonen J, Rivers C, Poon A, Bensley M, Sehnert A, Zellner C, Kane J, Aouizerat BE. Genetic variation in PLTP modulates lipoprotein profiles in hyperalphalipoproteinemia. Metabolism. 2008; 57:1719_ 1724. [PubMed: 19013296]

98. Kathiresan S, Willer CJ, Peloso G, Demissie S, Musnuru K, Schadt E, Lee K, Bennet D, Li Y, Tanaka T, Voight BF, Bonnycastle LL, Jackson AU, Crawford G, Surti A, Guiducci C, Burtt N, Parish S, Clarke R, Zelenika D, Kubalanza KA, Morken MA, Scott LJ, Stringham HM, Galan P, Swift AJ, Kuusisto J, Bergman RN, Sundvall J, Laakso M, Ferrucci L, Scheet P, Sanna S, Uda M, Yang Q, Lunetta K, Dupuis J, deBakker PI, O'Donnell CJ, Chambers JC, Kooner JS, Hercberg S, Meneton P, Lakatta EG, Scuteri A, Schlessinger D, Tuomilehto J, Collins FS, Groop L, Altshuler D, Collins R, Lathrop GM, Melander O, Salomaa V, Peltonen L, Orho-Melander M, Ordovas JM, Boehnke M, Abecasis GR, Mohike KL, Cupples LA. Common variants at 30 loci contribute to polygenic dyslipidemia. Nat Genet. 2009; 41:56-65. [PubMed: 19060906]

99. Jarvik GP, Rajagopalan R, Rosenthal EA, Wolfbauer G, McKinstry L, Vaze A, Brunzell J, Motulsky AG, Nickerson DA, Heagerty PJ, Wijsmann EM, Albers JJ. Genetic and nongenetic sources of variation in phospholipid transfer protein activity. J Lipid Res. 2010; 51:983-990. [PubMed: 19965587]

100. Vergeer M, Boekholdt SM, Sandhu MS, Ricketts SL, Wareham NJ, Brown MJ, de Faire U, Leander K, Gigante B, Kavousi M, Hofman A, Uitterlinden AG, van Duijn CM, Witteman JCM, Jukema JW, Schadt EE, van der Schoot E, Kastelein JJP, Khaw KT, Dullaart RPF, van Tol A, Trip MD, Dallinga-Thie GM. Genetic variation at the phospholipid transfer protein locus affects its activity and high-density lipoprotein size and is a novel marker of cardiovascular disease susceptibility. Circulation. 2010; 122:470-477. [PubMed: 20644014]

101. Teslovich TM, Musunuru K, Smith AV, Edmondson AC, Styllanou IM, Koseki M, Pirruccello JP, Ripatti S, Chasman DI, Willer CJ, Johansen CT, Fouchier SW, Isaacs A, Peloso GM, Barbalic M, Ricketts SL, Bis JC, Aulchenko YS, Thorleifsson G, Feitosa MF, Chambers J, OrhoMelander M, Melander O, Johnson T, Xi X, et al. Biological, clinical and population relevance of 95 loci for blood lipids. Nature. 2010; 488:707-713. [PubMed: 20686565] 
102. Kaess BM, Tomaszewski M, Braund PS, Stark K, Rafelt S, Fischer M, Hardwick R, Nelson CP, Debiec R, Huber F, Kremer W, Kalbitzer HR, Rose LM, Chasman DI, Hopewell J, Clarke R, Burton PR, Tobin MD, Hengstenberg C, Samani NJ. Large-scale candidate gene analysis of HDL particle features. PLoS ONE. 2011; 6:e14529. [PubMed: 21283740]

103. Cheung MC, Brown BG, Wolf AC, Albers JJ. Altered particle size distribution of apolipoprotein A-I-containing lipoproteins in subjects with coronary artery disease. J Lipid Res. 1991; 32:383394. [PubMed: 1906084]

104. Mora S, Otvos JD, Rifai N, Rosenson RS, Buring JE, Ridker PM. Lipoprotein particle profiles by nuclear magnetic resonance compared with standard lipids and apolipoproteins in predicting incident cardiovascular disease in women. Circulation. 2009; 119:931-939. [PubMed: 19204302]

105. Musunuru K, Orho-Melander M, Caulfield MP, Li S, Salameh WA, Reitz RE, Berglund G, Hedblad B, Enghström G, Williams PT, Kathiresan S, Melander O, Krauss RM. Ion mobility analysis of lipoprotein subfractions identifies three independent axes of cardiovascular risk. Arterioscler Thromb Vasc Biol. 2009; 29:1975-1980. [PubMed: 19729614]

106. Jiang XC, Bruce C, Mar J, Lin M, Ji Y, Francone OL, Tall AR. Targeted mutation of plasma phospholipid transfer protein gene markedly reduces high-density lipoprotein levels. J Clin Invest. 1999; 103:907-914. [PubMed: 10079112]

107. Jiang XC, Qin S, Qiao C, Kawano K, Lin M, Skold A, Xiao X, Tall AR. Apolipoprotein B secretion and atherosclerosis are decreased in mice with phospholipid transfer protein deficiency. Nat Med. 2001; 7:847-852. [PubMed: 11433351]

108. Jiang XC, Li Z, Liu R, Yang XP, Pan M, Lagrost L, Fisher EA, Williams KJ. Phospholipid transfer protein deficiency impairs apolipoprotein-B secretion from hepatocytes by stimulating a proteolytic pathway through a relative deficiency of vitamin $\mathrm{E}$ and an increase in intracellular oxidants. J Biol Chem. 2005; 280:18336-18340. [PubMed: 15734742]

109. Yang XP, Yan D, Qiao C, Liu RJ, Chen JG, Li J, Schneider M, Legrost L, Xiao X, Jiang XC. Increased atherosclerotic lesions in apoE mice with plasma phospholipid transfer protein overexpression. Arterioscler Thromb Vasc Biol. 2003; 23:1601-1607. [PubMed: 12855484]

110. Ehnholm S, van Dijk KW, van `t Hof B, van der Zee A, Olkkonen VM, Jauhiainen M, Hofker M, Havekes L, Ehnholm C. Adenovirus mediated overexpression of human phospholipid transfer protein alters plasma HDL levels in mice. J Lipid Res. 1998; 39:1248-1253. [PubMed: 9643356]

111. van Haperen R, van Tol A, van Gent T, Scheek L, Visser P, van der Kamp A, Grosveld F, de Crom R. Increased risk of atherosclerosis by elevated plasma levels of phospholipid transfer protein. J Biol Chem. 2002; 277:48938-48943. [PubMed: 12372822]

112. Masson D, Deckert V, Gautier T, Klein A, Desrumaux C, Viglietta C, Pais de Barros JP, Le Guern N, Grober J, Labbé J, Ménétrier F, Ripoll PJ, Leroux-Coyau M, Jolivet G, Houdebine LM, Lagrost L. Worsening of diet-induced atherosclerosis in a new model of transgenic rabbit expressing the human plasma phospholipid transfer protein. Arterioscler Thromb Vasc Biol. 2011; 31:766-774. [PubMed: 21252068]

113. Jiang X, Francone OL, Bruce C, Milne R, Mar J, Walsh A, Breslow JL, Tall AR. Increased prebeta-high density lipoprotein, apolipoprotein AI, and phospholipid in mice expressing the human phospholipid transfer protein and human apolipoprotein AI transgenes. J Clin Invest. 1996; 98:2373-2380. [PubMed: 8941656]

114. Föger B, Santamarina-Fojo S, Shamburek RD, Parrot CL, Talley GD, Brewer HB Jr. Plasma phospholipid transfer protein. Adenovirus-mediated overexpression in mice leads to decreased plasma high density lipoprotein (HDL) and enhanced hepatic uptake of phospholipids and cholesteryl esters from HDL. J Biol Chem. 1997; 272:27393-27400. [PubMed: 9341191]

115. van Haperen R, van Tol A, Vermeulen P, Jauhiainen M, van Gent T, van den Berg P, Ehnholm S, Grosveld F, van der Kamp A, de Crom R. Human plasma phospholipid transfer protein increases the antiatherogenic potential of high density lipoproteins in transgenic mice. Arterioscler Thromb Vasc Biol. 2000; 20:1082-1088. [PubMed: 10764677]

116. Jaari S, van Dijk KW, Olkkonen VM, van der Zee A, Metso J, Havekes L, Jauhiainen M, Ehnholm C. Dynamic changes in mouse lipoproteins induced by transiently expressed human phospholipid transfer protein (PLTP): importance of PLTP in prebeta-HDL generation. Comp Biochem Physiol B Biochem Mol Biol. 2001; 128:781-792. [PubMed: 11290460] 
117. Moerland M, Anghelescu N, Samyn H, van Haperen R, van Gent T, Stroubloulis J, van Tol A, Gorsveld F, de Crom R. Inducible expression of phospholipid transfer protein (PLTP) in transgenic mice: acute effects of PLTP on lipoprotein metabolism. Transgenic Res. 2007; 16:503-513. [PubMed: 17437182]

118. Moerland M, Samyn H, van Gent T, van Haperen R, Dallinga-Thie G, Grosveld F, van Tol A, de Crom A. Acute elevation of plasma PLTP activity strongly increases pre-existing atherosclerosis. Arterioscler Thromb Vasc Biol. 2008; 28:1277-1282. [PubMed: 18421000]

119. Albers JJ, Pitman W, Wolfbauer G, Cheung MC, Kennedy H, Tu AY, Marcovina SM, Paigen B. Relationship between phospholipid transfer activity and HDL levels and size among inbred mouse strains. J Lipid Res. 1999; 40:295-301. [PubMed: 9925659]

120. Lie J, de Crom R, van Gent T, van Haperen R, Scheek L, Sadeghi-Niaraki F, van Tol A. Elevation of plasma phospholipid transfer protein increases the risk of atherosclerosis despite lower apolipoprotein B-containing lipoproteins. J Lipid Res. 2004; 45:805-811. [PubMed: 14993244]

121. Samyn H, Moerland M, van Gent T, van Haperen R, Metso J, Grosveld F, Jauhiainen M, van Tol A, de Crom R. Plasma phospholipid transfer activity is essential for increased atherogenesis in PLTP transgenic mice: a mutation-inactivation study. J Lipid Res. 2008; 49:2504-2512. [PubMed: 18711210]

122. Valenta DT, Ogier N, Bradshaw G, Black AS, Bonnet DJ, Lagrost L, Curtiss LK, Desrumaux $\mathrm{CM}$. Atheroprotective potential of macrophage-derived phospholipid transfer protein in lowdensity lipoprotein receptor-deficient mice is overcome by apolipoprotein AI overexpression. Arterioscler Thromb Vasc Biol. 2006; 26:1572-1578. [PubMed: 16675720]

123. Valenta DT, Bulgrien JJ, Bonnet DJ, Curtiss LK. Macrophage PLTP is atheroprotective in LDLrdeficient ice with systemic PLTP deficiency. J Lipid Res. 2008; 49:24-32. [PubMed: 17928634]

124. Samyn H, Moerland M, van Gent T, van Haperen R, Gorsveld F, van Tol A, de Crom R. Elevation of systemic PLTP, but not macrophage-PLTP, impairs macrophage reverse cholesterol transport in transgenic mice. Atherosclerosis. 2009; 204:429-434. [PubMed: 19100548]

125. Vikstedt R, Ye D, Metso J, Hildebrand RB, van Berkel TJ, Ehnholm C, Jauhiainen M, van Eck M. Macrophage phospholipid transfer protein contributes significantly to total plasma phospholipid transfer activity and its deficiency leads to diminished atherosclerotic lesion development. Arterioscler Thromb Vasc Biol. 2007; 27:578-586. [PubMed: 17170377]

126. van Haperen R, Samyn H, Moerland M, van Gent T, Peeters M, Grosveld F, van Tol A, de Crom R. Elevated expression of phospholipid transfer protein bone marrow derived cells causes atherosclerosis. PLoS ONE. 2008; 3:e2255. [PubMed: 18509527]

127. Bérard AM, Föger B, Remaley A, Shamburek R, Vaisman BL, Talley G, Paigen B, Hoyt RF Jr. Marcovina S, Brewer HB Jr. Santamarina-Fojo S. High plasma HDL concentrations associated with enhanced atherosclerosis in transgenic mice overexpressing lecithin-cholesteryl acyltransferase. Nat Med. 1997; 3:744-749. [PubMed: 9212100]

128. Hoeg JM, Cantamarina-Fojo S, Bérard AM, Cornhill JF, Herderick EE, Feldman SH, Haudenschild CC, Vaisman BL, Hoyt RF Jr. Demosky SJ Jr. Kaumffman RD, Hazel CM, Marcovina SM, Brewer HB Jr. Overexpression of lecithin-cholesterol acyltransferase in transgenic rabbits prevents diet-induced atherosclerosis. Proc Natl Acad Sci USA. 1996; 93:11448-11453. [PubMed: 8876155]

129. Lu R, Arakawa R, Ito-Osumi C, Iwamoto N, Yokoyama S. ApoA-I facilitates ABCA1 recycleaccumulation to cell surface by inhibiting its intracellular degradation and increases HDL generation. Arterioscler Thromb Vasc Biol. 2008; 28:1820-1824. [PubMed: 18617649]

130. Okuhira K, Fitzgerald ML, Tamehiro N, Ohoka N, Suzuki K, Sawada J, Naito M, NishimakiMogami T. Binding of PDZ-RhoGEF to ATP-binding cassette transporter A1 (ABCA1) induces cholesterol efflux through RhoA activation and prevention of transporter degradation. J Biol Chem. 2010; 285:16369-16377. [PubMed: 20348106]

131. Tang C, Liu Y, Kessler PS, Vaughan AM, Oram JF. The macrophage cholesterol exporter ABCA1 functions as an anti-inflammatory receptor. J Biol Chem. 2009; 284:32336-32343. [PubMed: 19783654]

132. Dong W, Albers JJ, Vuletic S. Phospholipid transfer protein reduces phosphorylation of tau in human neuronal cells. J Neurosci Res. 2009; 87:3176-3185. [PubMed: 19472218] 
133. Guizzetti M, Chen J, Oram JF, Tsuji R, Dao K, Möller T, Costa LG. Ethanol induces cholesterol efflux and up-regulates ATP-binding cassette cholesterol transporters in fetal astrocytes. J Biol Chem. 2007; 282:18740-18749. [PubMed: 17478430]

134. Krapfenbauer K, Yoo BC, Kim SH, Cairns N, Lubec G. Differential display reveals downregulation of the phospholipid transfer protein (PLTP) at the mRNA level in brains of patients with Down syndrome. Life Sci. 2001; 68:2169-2179. [PubMed: 11324722]

135. Demeester N, Castro G, Desrumaux C, de Geitere C, Fruchart JC, Santens P, Mulleners E, Engelborghs S, de Deyn PP, Vandekerckhove J, Rosseanu M, Labeur C. Characterization and functional studies of lipoproteins, lipid transfer proteins, and lecithin:cholesterol acylthransferase in CSF of normal individuals and patients with Alzheimer's disease. 2000; 41:963-974.

136. Gander R, Eller P, Kaser S, Theurl I, Walter D, Sauper T, Ritsch A, Patsch JR, Föger B. Molecular characterization of rabbit phospholipid transfer protein: choroid plexus and ependyma synthesize high levels of phospholipid transfer protein. J Lipid Res. 2002; 43:636-645. [PubMed: 11907147]

137. Vuletic S, Li G, Peskind ER, Kennedy H, Marcovina SM, Leverenz JB, Petrie EC, Lee VM, Galasko D, Schellenberg GD, Albers JJ. Apolipoprotein E highly correlates with AbetaPP- and tau-related markers in human cerebrospinal fluid. J Alzheimers Dis. 2008; 15:409-417. [PubMed: 18997294]

138. Arai K, Ikegaya Y, Nakatani Y, Kudo I, Nishiyama N, Matsuki N. Phospholipase A2 mediates ischemic injury in the hippocampus: a regional difference of neuronal vulnerability. Eur.J. Neurosci. 2001; 13:2319-2323. [PubMed: 11454037]

139. Heimer, L. Hippocampal formation.. In: Heimer, L., editor. The Human Brain and Spinal Cord, Functional Neuroanatomy and Dissection Guide. Springer-Verlag; New York: 1995. p. 423-431.

140. Gautier T, Klein A, Deckert V, Desrumaux C, Ogier N, Sberna AL, Paul C, Le Guern N, Athias A, Montange T, Monier S, Piard F, Jiang XC, Masson D, Lagrost L. Effect of plasma phospholipid transfer protein deficiency on lethal endotoxemia in mice. J Biol Chem. 2008; 283:18702-18710. [PubMed: 18458077]

141. Vuletic S, Taylor BA, Tofler GH, Chait A, Marcovina SM, Schenck K, Albers JJ. SAA and PLTP activity in plasma of periodontal patients before and after full-mouth tooth extraction. Oral Dis. 2008; 14:514-519. [PubMed: 18826383]

142. Genetic association between PLTP gene polymorphisms and Alzheimer's disease in a Japanese population. Dement Geriatr Cogn Disord. 2010; 30:78-82. [PubMed: 20714154]

143. Desrumaux C, Risold PY, Schroeder H, Deckert V, Masson D, Athias A, Laplanche H, Le Guern N, Blache D, Jiang XC, Tall AR, Desor D, Lagrost L. Phospholipid transfer protein (PLTP) deficiency reduces brain vitamin E content and increases anxiety in mice. FASEB J. 2005; 19:296-297. [PubMed: 15576481]

144. Kono S, Otsuji A, Hattori H, Shirakawa K, Suzuki H, Miyajima H. Ataxia with vitamin E deficiency with a mutation in a phospholipid transfer protein. J Neurol. 2009; 256:1180-1181. [PubMed: 19252769]

145. Yeoh EJ, Ross ME, Shurtleff SA, Williams WK, Patel D, Mahfouz R, Behm FG, Raimondi SC, Relling MV, Patel A, Cheng C, Campana D, Wilkins D, Zhou X, Li J, Liu H, Pui CH, Evans WE, Naeve C, Wong L, Downing JR. Classification, subtype discovery, and prediction of outcome in pediatric acute lymphoblastic leukemia by gene expression profiling. Cancer Cell. 2002; 1:133-143. [PubMed: 12086872]

146. Shi X, Cao S, Kitsuhashi M, Xiang Z, Ma X. Genome-wide analysis of molecular changes in IL-12-induced control of mammary carcinoma via IFN- $\gamma$-independent mechanisms. J Immunol. 2004; 172:4111-4122. [PubMed: 15034023]

147. Skamrov AV, Nechaenko MA, Goryunova LE, Feoktistova ES, Khaspekov GL, Kovalevsky DA, Vinnitsky LI, Sheremeteva GF, Beabealashwilli RS. Gene expression analysis to identify mRNA markers of cardiac myxoma. J Mol Cell Cardiol. 2004; 37:717-733. [PubMed: 15350845]

148. Kuk C, any Kulasingam V, Gunawardana COT, Smith CRI, Bartech I, Diamonds EI. Mining the ovarian cancer ascites proteome for potential ovarian cancer biomarkers. Mol Cell Proteomics. 2009; 8:661-669. [PubMed: 19047685] 
149. Francis P, Namløs HM, Müller C, Edén P, Femebro J, Berner J-M, Bjerkehagen B, Åkerman M, Bendahl P-O, Isinger A, Rydholm A, Myklebost O, Nilbert M. Diagnostic and prognostic gene expression signatures in 177 soft tissue sarcomas: hypoxia-induced transcription profile signifies metastatic potential. BMC Genomics. 2007; 8:73. [PubMed: 17359542]

150. Rohrbeck A, Borlak J. Cancer genomics identifies regulatory gene networks associated with the transition from dysplasia to advanced lung adenocarcinomas induced by c-Raf- 1 . PLoS One. 2009; 4:e7315. [PubMed: 19812696]

151. Sardana G, Marshall J, Diamandis EP. Discovery of candidate tumor markers for prostate cancer via proteomic analysis of cell culture-conditioned medium. Clin Chem. 2007; 53:429-437. [PubMed: 17259234]

152. Haque T, Faury D, Albrecht S, Lopez-Aguilar E, Hauser P, Garami M, Hanzély Z, Bognár L, Del Maestro RF, Atkinson J, Nantel A, Jabado N. Gene expression profiling from formalin-fixed paraffin-embedded tumors of pediatric glioblastoma. Hum Cancer Biol. 2007; 13:6284-6292.

153. Ferkingstad E, Frigessi A, Lyng H. Indirect genomic effects on survival from gene expression data. Genome Biol. 2008; 9:R58-R72. [PubMed: 18358079]

154. van der Auwera I, Yu W, Suo L, van Neste L, van Dam P, van Marck EA, Pauwels P, Vermeulen PB, Dirix LY, van Leare SJ. Array-based DNA methylation profiling for breast cancer subtype discrimination. PLoS ONE. 2010; 5:e12616. [PubMed: 20830311]

155. Krasilnikov MA. Phosphatidylinositol-3 kinase dependent pathways: the role in control of cell growth, survival, and malignant transformation. Biochemistry Mosc. 2000; 65:59-67. [PubMed: 10702641]

156. Vuletic S, Dong W, Wolfbauer G, Day JR, Albers JJ. PLTP is present in the nucleus, and its nuclear export is CRM1-dependent. Biochim Biophys Acta. 2009; 1793:584-591. [PubMed: 19321130]

157. Murdoch SJ, Kahn SE, Albers JJ, Brunzell JD, Purnell JQ. PLTP activity decreases with weight loss: changes in PLTP are associated with changes in subcutaneous fat and FFA but not IAF or insulin sensitivity. J Lipid Res. 2003; 44:1705-1712. [PubMed: 12837855]

158. de Vries R, Kappelle PJ, Dallinga-Thie GM, Dullaart RP. Plasma phospholipid transfer protein activity is independently determined by obesity and insulin resistance in non-diabetic subjects. Atherosclerosis. 2011 In Press.

159. de Vries R, Dallinga-Thie GM, Smit AJ, Wolffenbuttel BH, van Tol A, Dullaart RP. Elevated plasma phospholipid transfer protein activity is a determinant of carotid intime-media thickness in type 2 diabetes mellitus. Diabetologia. 2006; 49:398-404. [PubMed: 16374627]

160. Attia N, Nakbi A, Smaoui M, Chaaba R, Moulin P, Hammami S, Hamda KB, Chanussot F, Hammami M. Increased phospholipid transfer protein activity associated with the impaired cellular cholesterol efflux in type 2 diabetic subjects with coronary artery disease. Tohoku J Exp Med. 2007; 213:129-137. [PubMed: 17917406]

161. de Vries R, Groen AK, Perton FG, Dallinga-Thie GM, van Wijland MJ, Dikkeschei LD, Wolffenbuttel BH, van Tol A, Dullaart RP. Increased cholesterol efflux from cultured fibroblasts to plasma from hypertriglyceridemic type 2 diabetic patiens: roles of pre $\beta$-HDL, phospholipid transfer protein and cholesterol esterification. Atherosclerosis. 2008; 196:733-741. [PubMed: 17275009]

162. de Vries R, Kerstens MN, Sluiter WJ, Groen AK, van Tol A, Dullaart RP. Cellular cholesterol efflux to plasma from moderately hypercholesterolaemic type 1 diabetic patients is enhanced, and is unaffected by simvastatin treatment. Diabetologia. 2005; 48:1105-1113. [PubMed: 15875154]

163. Tang C, Kanter JE, Bornfeldt KE, LaBoeuf RC, Oram JF. Diabetes reduces the cholesterol exporter ABCA1 in mouse macrophages and kidneys. J Lipid Res. 2010; 51:1719-1728. [PubMed: 19965614] 


\section{Review Highlights}

- PLTP plays a central role in lipoprotein metabolism.

- PLTP is involved in reverse cholesterol transport.

- Approximately half of human plasma PLTP is inactive in phospholipid transfer.

- Plasma PLTP complexes contain proteins involved in immunity and inflammation.

- PLTP-ABCA1 interaction plays a role in signal transduction. 